Marquette University

e-Publications@Marquette

Civil and Environmental Engineering Faculty

Civil and Environmental Engineering, Department

Research and Publications

$12-10-2018$

\title{
Meta-Analysis of Non-Reactive Phosphorus in Water, Wastewater, and Sludge, and Strategies to Convert it for Enhanced Phosphorus Removal and Recovery
}

Kaushik Venkiteshwaran

Marquette University

Patrick J. McNamara

Marquette University, patrick.mcnamara@marquette.edu

Brooke K. Mayer

Marquette University, Brooke.Mayer@marquette.edu

Accepted version. Science of the Total Environment, Vol. 644 (December 10, 2018): 661-674. DOI. (C) 2018 Elsevier B.V. Used with permission. 
Marquette University

\section{e-Publications@Marquette}

\section{Civil and Environmental Engineering Faculty Research and Publications/College of Engineering}

This paper is NOT THE PUBLISHED VERSION; but the author's final, peer-reviewed manuscript.

The published version may be accessed by following the link in the citation below.

Science of the Total Environment, Vol. 64, (December, 2018): 661-674. DOI. This article is (C) Elsevier and permission has been granted for this version to appear in $\underline{\mathrm{e}-}$ Publications@Marquette. Elsevier does not grant permission for this article to be further copied/distributed or hosted elsewhere without the express permission from Elsevier.

\section{Contents}

Highlights

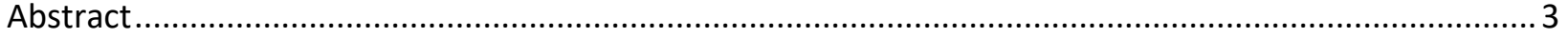

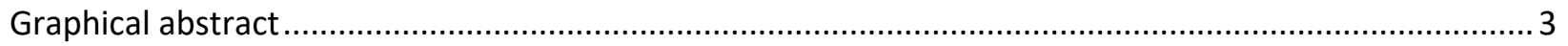

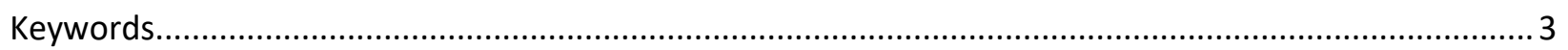

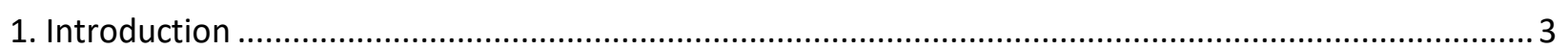

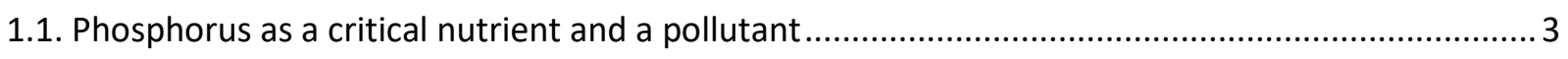

1.2. Objectives: what is the big deal about NRP and what can we do about it? .................................... 5

2. All $\mathrm{P}$ is not created equal: why should we worry about NRP? .......................................................... 5

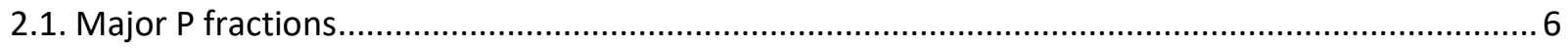

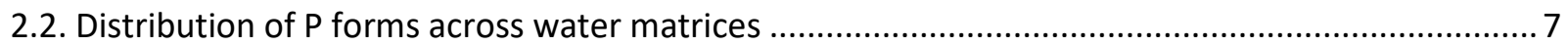

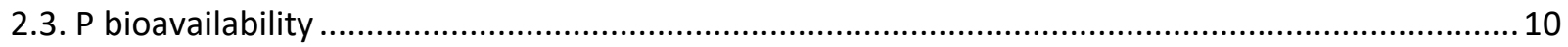

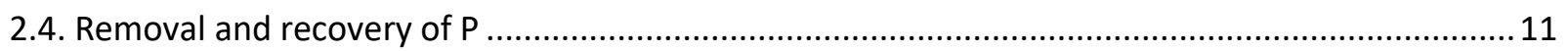

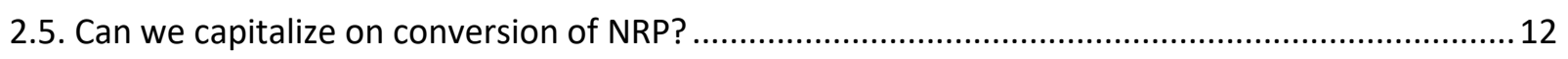

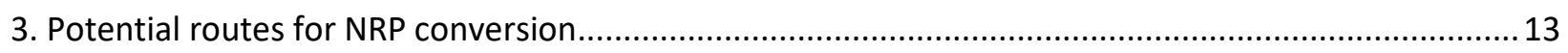

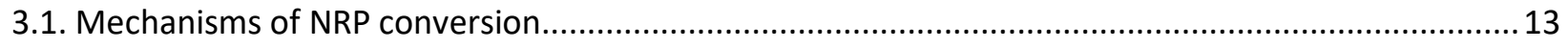

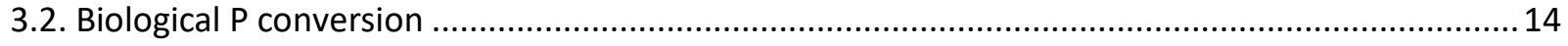




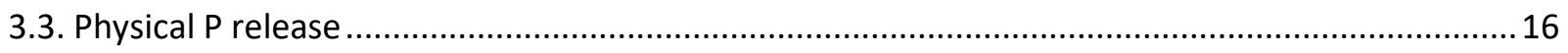

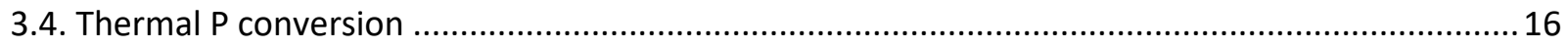

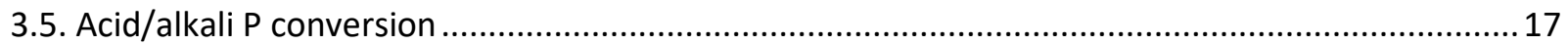

3.6. Redox reactions: P conversion using advanced oxidation processes .......................................... 17

4. Comparative assessment of $\mathrm{P}$ conversion process applications........................................................... 18

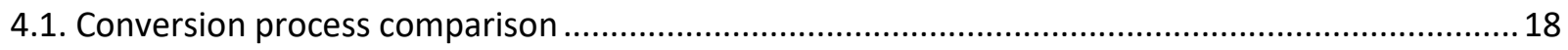

4.2. Relevance of $\mathrm{P}$ conversion processes to applications beyond sludge solubilization...................... 20

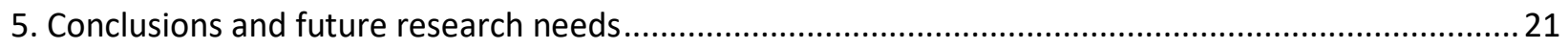

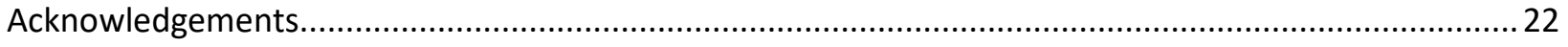

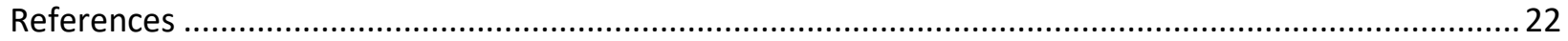

\section{Meta-analysis of Non-reactive Phosphorus in Water, Wastewater, and Sludge, and Strategies to Convert It for Enhanced Phosphorus Removal and Recovery}

\section{Kaushik Venkiteshwaran}

Department of Civil, Construction and Environmental Engineering, Marquette University, Milwaukee, WI

\section{Patrick J. McNamara}

Department of Civil, Construction and Environmental Engineering, Marquette University, Milwaukee, WI

\section{Brooke K. Mayer}

Department of Civil, Construction and Environmental Engineering, Marquette University, Milwaukee, WI

\section{Highlights}

- Meta-analysis reveals non-reactive P (NRP) comprises a substantial portion of total P.

- NRP must be physically, chemically, or biologically converted to soluble RP for recovery.

- No technologies have been implemented to recover soluble NRP from water matrices.

- $\mathrm{P}$ conversion processes must be specifically tested in water, wastewater, and sludge. 


\section{Abstract}

Current and future trends indicate that mining of natural phosphorus $(P)$ reserves is occurring faster than natural geologic replenishment. This mobilization has not only led to $P$ supply concerns, but has also polluted many of the world's freshwater bodies and oceans. Recovery and reuse of this nuisance $P$ offers a long-term solution simultaneously addressing mineral $\mathrm{P}$ accessibility and P-based pollution. Available physical, chemical, and biological $P$ removal/recovery processes can achieve low total P (TP) concentrations $(\leq 100 \mu \mathrm{g} / \mathrm{L}$ ) and some processes can also recover $P$ for direct reuse as fertilizers (e.g., struvite). However, as shown by our meta-analysis of over 20,000 data points on P quantity and $P$ form, the $P$ in water matrices is not always present in the reactive $P(R P)$ form that is most amenable to recovery for direct reuse. Thus, strategies for removing and recovering other $\mathrm{P}$ fractions in water/wastewater are essential to provide environmental protection via $\mathrm{P}$ removal and also advance the circular $\mathrm{P}$ economy via $\mathrm{P}$ recovery. Specifically, conversion of non-reactive $\mathrm{P}$ (NRP) to the more readily removable/recoverable RP form may offer a feasible approach; however, extremely limited data on such applications currently exist. This review investigates the role of NRP in various water matrices; identifies NRP conversion mechanisms; and evaluates biological, physical, thermal, and chemical processes with potential to enhance P removal and recovery by converting the NRP to RP. This information provides critical insights into future research needs and technology advancements to enhance $P$ removal and recovery.

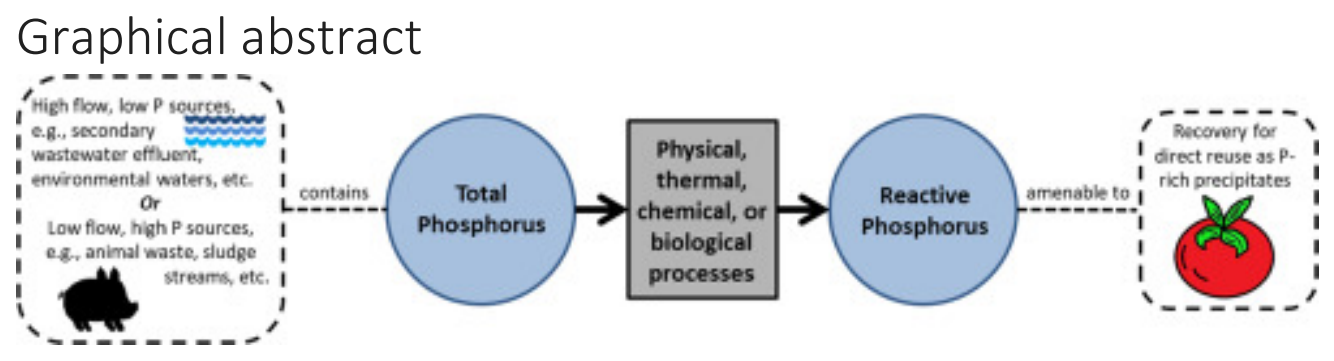

\section{Keywords}

Advanced oxidation processes (AOP); Conversion; Hydrolysis; Organic phosphorus; Orthophosphates; Soluble reactive phosphorus (SRP)

\section{Introduction}

\subsection{Phosphorus as a critical nutrient and a pollutant}

Paradoxically, phosphorus $(\mathrm{P})$ is simultaneously an important non-renewable agricultural nutrient and an environmental pollutant. On one hand, modern human society depends on $\mathrm{P}$ to sustain the global food supply. Rapid increases in human population and the subsequent need for high agricultural productivity have led to substantial increases in fertilizer use. Currently, P is primarily obtained from subsurface mining of phosphate minerals. Unfortunately, these mineral $P$ resources replenish on geologic time scales, making $P$ an essentially non-renewable resource, characterized by rapidly depleting finite reserves. This, coupled with the fact that $90 \%$ of minable $\mathrm{P}$ is found in only five countries around the world, has led to substantial increases in fertilizer prices (Childers et al., 2011; Cordell et al., 2009; Liu et al., 2008). 
On the other hand, $\mathrm{P}$ is also an overabundant water pollutant. The simplified schematic in Fig. 1 illustrates anthropogenic $P$ flows and distributions in global food production. Approximately $80 \%$ of mined $\mathrm{P}$ (16.5 \pm 3 million metric tonnes/yr) is used as fertilizer for global food production, and almost $35 \%$ (6.3 \pm 3 million metric tonnes/yr) of that $P$ makes its way to surface waters (Cordell and White, 2014). This $P$ can enter streams as nonpoint runoff from urban and agricultural lands and point sources such as municipal and industrial wastewater treatment facilities (Bravo et al., 2017; USEPA, 1998). In most freshwaters, $P$ is the limiting nutrient, or nutrient in least supply relative to demand (typical $N: P$ ratios are $>15: 1$ (Correll, 1999)). Thus, excess $\mathrm{P}$ makes these waters prone to extraordinary phytoplankton growth. The resulting eutrophication adversely affects the ability of a water body to serve as a drinking water supply, recreational resource, or fishery as it eventually leads to color, odor, turbidity, loss of dissolved oxygen, and elimination of fish habitat (USEPA, 1995). Eutrophication can be costly in terms of human and environmental health as well as economic impacts, with annual damages associated with freshwaters estimated at $\$ 2.2$ billion in the United States alone (Dodds et al., 2009). This is surely exceeded by the as yet undetermined total value of ecosystem disservices (Mayer et al., 2016). To control ecological degradation, the United States Environmental Protection Agency (USEPA) has recommended a limit of $50 \mu \mathrm{g} / \mathrm{L}$ total phosphorus (TP) for streams entering lakes and $100 \mu \mathrm{g}-\mathrm{TP} / \mathrm{L}$ for flowing waters (USEPA, 1986). However, some P-limited surface waters are susceptible to algal blooms even at these low levels (Mayer et al., 2013; USEPA, 1998). These findings have led to more stringent water quality goals and standards, e.g., as low as 5-10 $\mu \mathrm{g}-\mathrm{TP} / \mathrm{L}$ in ecologically-sensitive zones like the Great Lakes and Everglades (USEPA, 1995, USEPA, 1986).

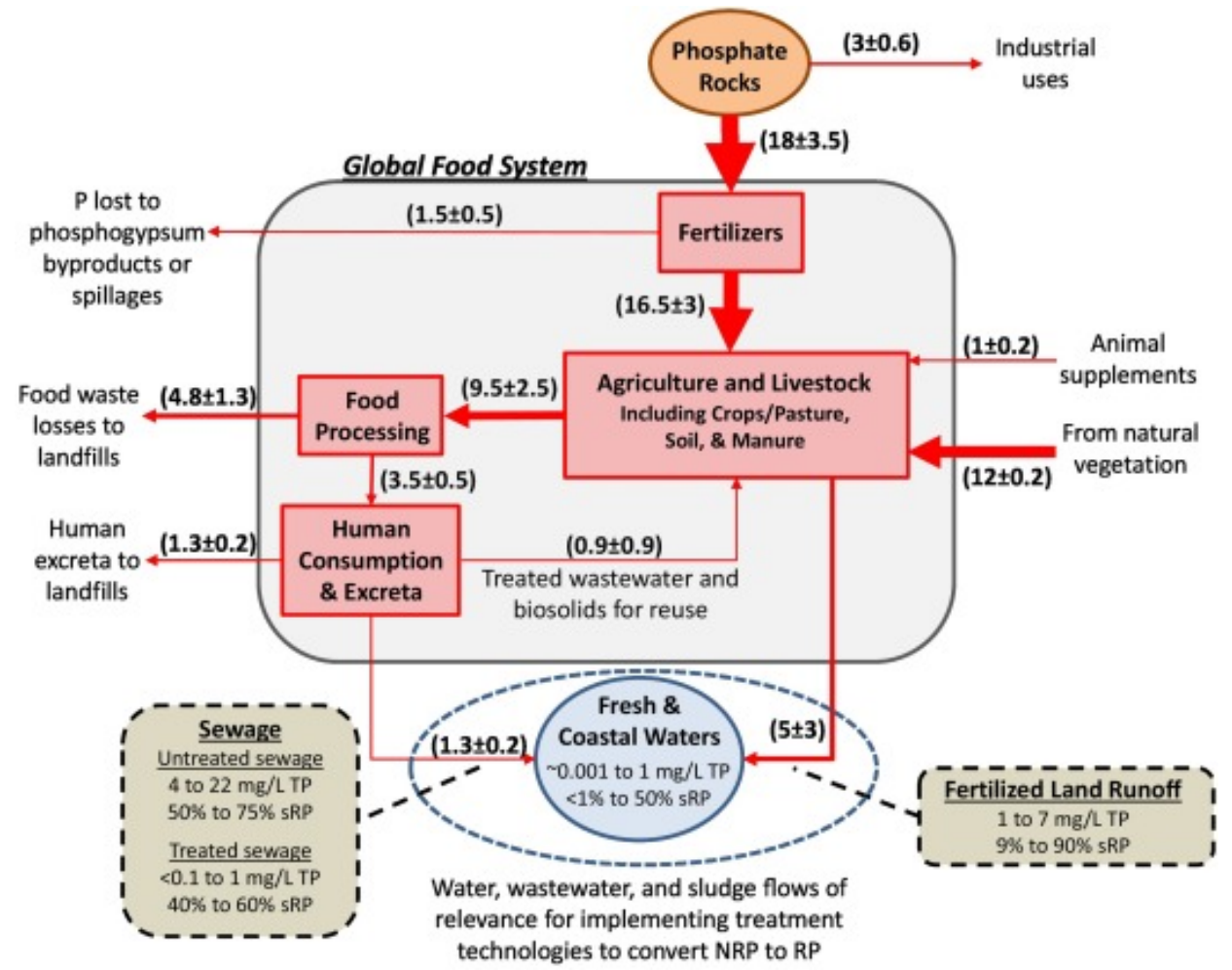

Fig. 1. Anthropogenic phosphorus (P) flows (million metric tonnes of $P$ per year) for global food production, adapted from Cordell and White (2014). The thickness of each arrow indicates the relative magnitude of each $P$ flow. The majority of mined $P(18 \pm 3.5$ million tonnes of $P$ per year) is used in fertilizers, approximately $35 \%$ $(6.3 \pm 3$ million tonnes of $P$ per year $)$ of which is lost to surface waters. Soluble reactive $P(s R P)$ accounts for a 
majority of total P (TP) in many waters, but a substantial proportion of the TP in point source sewage and sludge, non-point runoff, and environmental waters can consist of non-reactive P (NRP), which may be more difficult to remove and is not directly recoverable.

A long-term sustainable solution for addressing the dual problems of mineral P scarcity and P-based eutrophication is to remove $P$ from water and wastewater streams and recover it for beneficial reuse, e.g., as an agricultural fertilizer. Researchers have identified a wide range of innovative physical, thermal, chemical, and biological technologies to remove and recover P (Mayer et al., 2013; Mehta et al., 2015; Morse et al., 1998; Rittmann et al., 2011). However, existing processes can struggle to consistently achieve increasingly lower TP standards (Neethling et al., 2010; Stephens et al., 2004; USEPA, 2007). A key factor contributing to this difficulty is that existing processes cannot remove all $P$ fractions (Gu et al., 2011; USEPA, 2010). In particular, non-reactive $P$ (NRP) poses a challenge for $P$ removal and recovery.

\subsection{Objectives: what is the big deal about NRP and what can we do about it?}

A considerable proportion of TP in many waters, including both point and non-point sources, consists of NRP. NRP is not readily reactive and must first be converted to reactive $\mathrm{P}$ (RP, or orthophosphates) before chemical reactions can proceed and P recovery strategies can be implemented (APHA, 2012; Rittmann et al., 2011). To effectively limit eutrophication risks and substantially satisfy anthropogenic $P$ demands, we must maximize capture of all of the lost $P$, including NRP, which historically has been overlooked as a specific target for recovery technologies. This extends to capitalizing on opportunities at a variety of scales and from a variety of flows (e.g., animal, municipal, and industrial wastewater; environmental waters and agricultural runoff; and organic and industrial waste). The objective of the review article is to offer a first step toward addressing this need via 1) a quantitative assessment of the presence of NRP in water, wastewater, and sludge matrices; and 2) a forward-looking assessment of NRP conversion mechanisms and the associated strategies for improving $P$ management by converting the NRP to RP forms amenable for subsequent recovery and reuse as P-rich products. This article addresses a major gap in the literature, as NRP is not effectively targeted for removal/recovery and there are very few assessments of technologies specifically focused on conversion of NRP in water, wastewater, or sludge. Thus, we focus on identifying a suite of potential technologies such that future research can directly establish NRP conversion efficacy.

\section{All P is not created equal: why should we worry about NRP?}

In water, $\mathrm{P}$ can be present in many different forms, which vary dramatically in terms of environmental impacts, removability, recoverability, and reusability for agricultural applications. Historically, the NRP fraction has been largely ignored as a target for removal and recovery; however, we contend that this fraction cannot be ignored on the basis that:

1) NRP counts toward TP effluent discharge limits at wastewater treatment facilities, but is typically less amenable to removal, which can be a challenge for removal to ultra-low TP levels. 2) To maximize $P$ recovery in support of a circular $P$ economy, we need to "unlock" this largely unavailable pool of NRP.

3) In environmental waters, NRP eventually converts to RP, which contributes to eutrophication potential (although the timing of NRP conversion varies dramatically as a function of chemical and biological water quality parameters and environmental conditions such as temperature and sunlight exposure). 


\subsection{Major $P$ fractions}

The different forms of $\mathrm{P}$ typically found in water matrices, including soluble (sP; which can pass through a $0.45 \mu \mathrm{m}$ filter) and particulate (pP; retained on a $0.45 \mu \mathrm{m}$ filter) forms, are summarized in Fig. 2.

Particulate $\mathrm{P}$ fractions can be removed from water matrices using physical separation techniques, but the suitability of this pP for subsequent reuse depends on the extent of its reactivity.

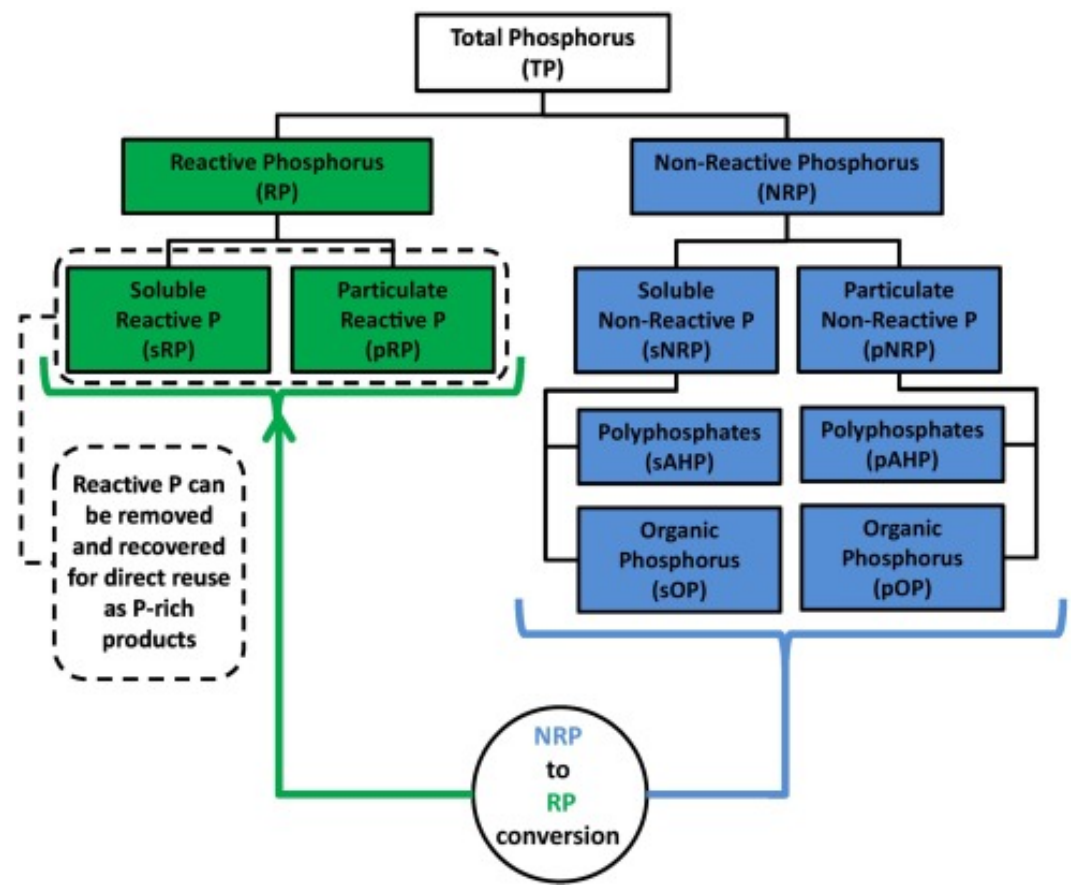

Fig. 2. Different forms of phosphorus (P) in water, modified from APHA (2012). Only the reactive phosphorus (RP) fractions (shaded in green) can be removed and recovered for direct reuse. The NRP fractions (shaded in blue) must be converted to RP prior to recovery and reuse as P-rich products. (For interpretation of the references to color in this figure legend, the reader is referred to the web version of this article.)

Reactive $\mathrm{P}(\mathrm{RP})$, also known as inorganic phosphorus, orthophosphate, or molybdate reactive $\mathrm{P}$, refers to the operational TP fraction that is readily available for chemical reactions via coulombic attraction to cations (APHA, 2012; McKelvie, 2005; Rittmann et al., 2011).

The NRP fraction, also known as condensed or acid hydrolysable phosphorus (AHP) or organic phosphorus (OP), includes inorganic polyphosphates (metaphosphates and di, tri, and tetrapolyphosphates) (APHA, 2012; USEPA, 2010). Polyphosphates can occur naturally as many microorganisms accumulate and store $P$ in this form as energy reserves (USEPA, 2010; Yuan et al., 2012). Use of polyphosphoric compounds in fertilizers and anti-corrosive agents also contributes to concentrations of these species in water (USEPA, 2007). Natural OP comes from plants, animals, or microbial cellular materials such as nucleic acids, nucleotides, and phospholipids (Murphy, 2007; USEPA, $\underline{2010}$ USEPA, 1986). Synthetic sources of soluble OP (sOP) come from organophosphorus compounds in pesticides (e.g., malathion), herbicides (e.g., glyphosate), flame retardants (e.g., tris(2-ethylhexyl)phosphate), and plasticizers (Meyer and Bester, 2004; Yu, 2002). In some environmental waters, OP can be at least as abundant as inorganic P (Cade-Menun et al., 2006; Karl and Björkman, 2001; Worsfold et al., 2016); for example, sOP may constitute on the order of 30-60\% of TP 
in lakes (AWWA, 1970). In the context of the environmental biogeochemical P cycle, NRP (e.g., in the form of apatite minerals) is unavailable for chemical reactions; however, P can be released to soluble, more bioavailable forms via natural processes such as weathering (Filippeli, 2002).

Fig. 3 illustrates several example P compounds from each of the major fractions: soluble reactive P (sRP), soluble non-reactive $P$ ( $s N R P)$, particulate RP ( $p R P)$, and particulate NRP ( $p N R P)$. Each of these compounds may be present in water, wastewater, or sludge matrices, albeit at varying concentrations.

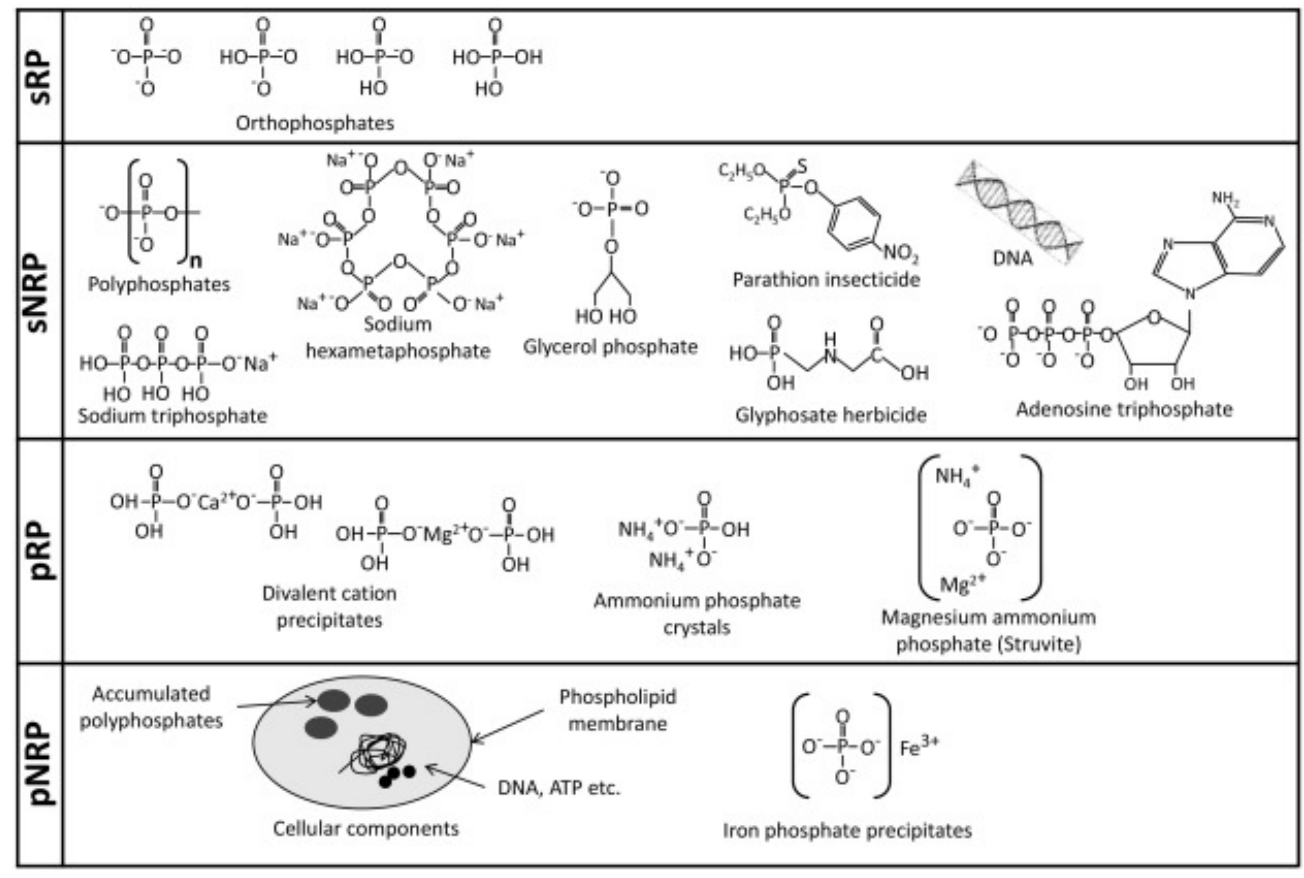

Fig. 3. Examples of phosphorus-containing compounds in the soluble reactive phosphorus (sRP), soluble nonreactive phosphorus (sNRP), particulate reactive phosphorus (pRP), and particulate non-reactive phosphorus (pNRP) forms.

\subsection{Distribution of $P$ forms across water matrices}

Water matrices of interest for $\mathrm{P}$ removal and/or recovery, including sludges, manures, wastewaters, and environmental waters, may vary in both $\mathrm{P}$ concentration and composition. Here we examine both of these dimensions across the water matrices of interest.

Although TP concentrations vary widely both spatially and temporally, they typically follow the trend manure $>$ sludge $>$ wastewater $>$ environmental waters, as shown in Fig. 4, Fig. 5 . In environmental waters, TP concentrations range from approximately $0.001-100 \mathrm{mg}-\mathrm{TP} / \mathrm{L}$, with $0.005-1 \mathrm{mg}-\mathrm{TP} / \mathrm{L}$ being more common in lakes and rivers (AWWA, 1970). In North Pacific ocean waters, Yoshimura et al. (2007) reported TP concentrations from 0.0037 to $0.057 \mathrm{mg} / \mathrm{L}$. Concentrations of NRP in the particulate OP (pOP) form ranged from 0.00028 to $0.0034 \mathrm{mg} / \mathrm{L}$, while sOP varied from 0.0031 to $0.0068 \mathrm{mg} / \mathrm{L}$. Effluent from sewage treatment without specific $P$ removal processes may contain approximately $3-10 \mathrm{mg}-\mathrm{P} / \mathrm{L}$, whereas with P removal, concentrations are typically $\leq 1 \mathrm{mg} / \mathrm{L}$ (AWWA, 1970; Egle et al., 2015). In agricultural drainage waters, $P$ concentrations are often on the order of $0.05-1 \mathrm{mg} / \mathrm{L}$ (AWWA, 1970), up to approximately $7 \mathrm{mg} / \mathrm{L}$. 


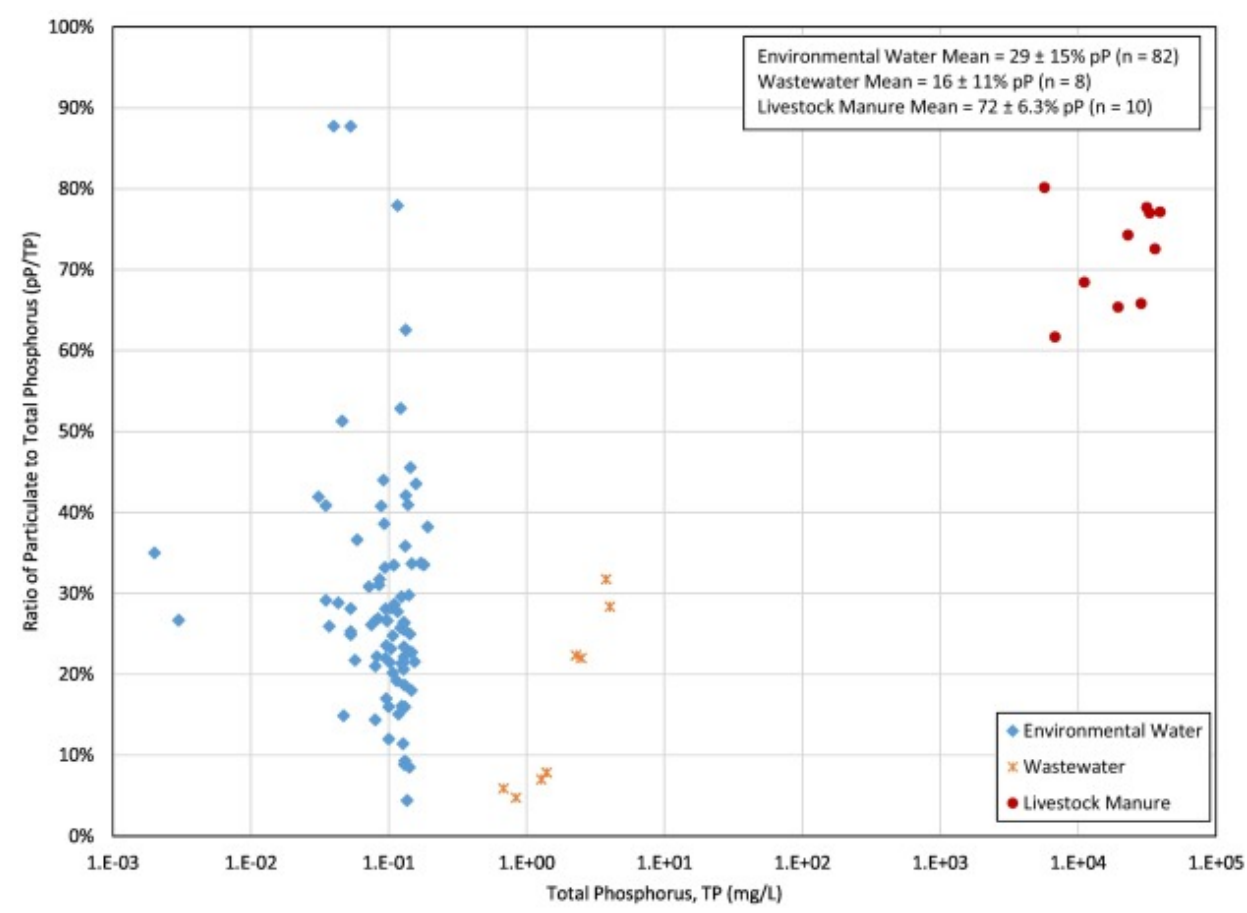

Fig. 4. Fraction of total phosphorus (TP) in the particulate phosphorus (pP) form for select environmental waters, wastewaters, and livestock manures. Additional description of the datasets is provided in the Supplementary Information, SI, Section S1.1. 

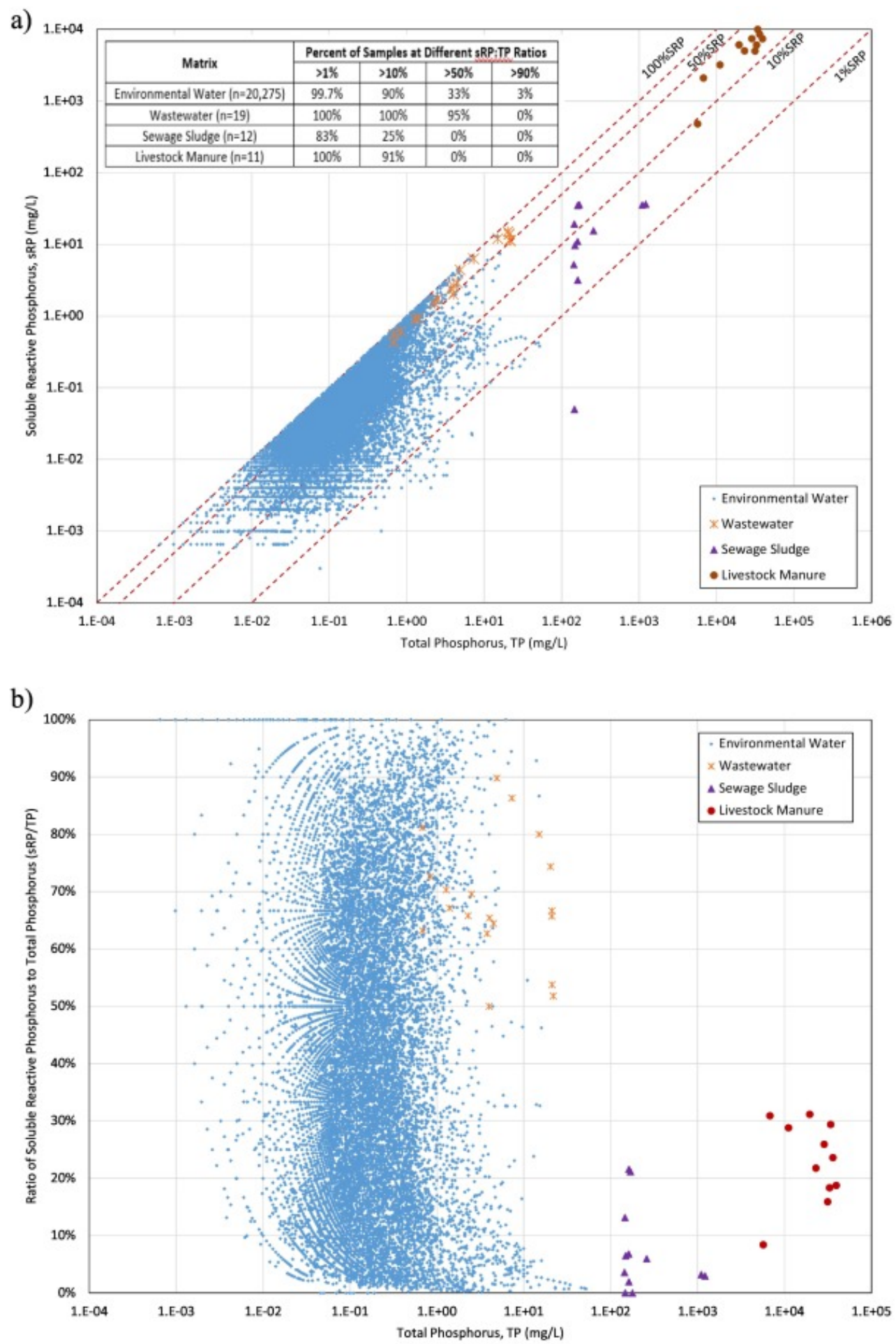

Fig. 5. a) Soluble reactive phosphorus (sRP) versus total phosphorus (TP) concentrations for select environmental waters, wastewaters, sewage sludges, and livestock manures. b) Data shown as the fraction of TP in the SRP form (sRP:TP). Data for environmental waters includes over 20,000 data points from 4000 sites across the US. Additional descriptions of the datasets are provided in the Supplementary Information, SI, Sections S1.1-S1.2. The curvilinear pattern apparent in $\mathrm{b}$ ) is ostensibly an artifact of analytical quantification capabilities and significant figure reporting for low $\mathrm{P}$ concentrations combined with the logarithmic scale used to graph the large range in values. 
The relative magnitude of the $\mathrm{pP}$ fraction varies by water matrix, specific waterbody, and location/time. Fig. 4 illustrates the trend in $\mathrm{pP}$ across water matrices, where manures contain the highest levels of particulate-associated P. In environmental waters, pP varies widely, but can be substantial (Jarvie et al., 2006), even accounting for the majority of TP in some cases, e.g., 56\% in the Pee Dee river inlet in South Carolina (Cade-Menun et al., 2006). Similarly, Aydin et al. (2010) reported $3.7 \mathrm{mg}-\mathrm{TP} / \mathrm{L}$ in the Asi River (Samandag, Antakya, Turkey), of which $>99 \%$ was present as pRP. In contrast, pP in the textile industrial wastewater is low. The domestic wastewaters are also relatively low, but pP levels depend on locationspecific factors. For example, Dueñas et al. (2003) observed pP fractions contributing $20-100 \%$ of the 8$16 \mathrm{mg}-\mathrm{TP} / \mathrm{L}$ influent at two municipal wastewater treatment plants. Fig. S1 in the Supplementary Information (SI) shows that concentrations of TP and pP are different amongst the environmental waters, wastewaters, and livestock manures.

The variability of sRP content across different water matrices is shown in Fig. 5 . Also illustrated is the temporal and spatial variability in the large dataset of environmental waters (22,750 data points from 4000 sites across the US). As shown, wastewaters generally exhibit the highest proportion of sRP, while sludges tend to have the lowest SRP. These findings coincide with the inverse trends observed for $\mathrm{pP}$ across matrices. Again, environmental waters are highly variable, spanning the entire spectrum of 0 to $100 \%$ sRP, with TP levels typically less than the other matrices. A principle component (PCA) analysis was performed in $\mathrm{R}$ to assess the similarity amongst the grouped water matrices with respect to concentrations of TP and SRP. As shown in Fig. S4 of the SI, levels of TP and SRP in sewage sludges were dissimilar from wastewater. The wastewaters were also different from the manure.

Beyond TP, sRP, and some limited pP data, the other $\mathrm{P}$ fractions are much less frequently reported. Furthermore, the actual P-containing compounds present in the different water matrices are seldom identified, with the exception of laboratory spiking studies. For example, the American Water Works Association notes that "almost no information is available to identify the specific compounds or groups of compounds that may make up a dissolved organic-phosphorus fraction in waste effluents, agricultural soil-drainage water, or surface water" (AWWA, 1970). In particular, the chemical constituents of the OP and colloidal $P$ fractions remain poorly characterized, which hampers understanding of environmental fate (e.g., bioavailability and mineralization potential) as well as design of effective approaches for $P$ removal and recovery (Venkatesan et al., 2018).

\subsection{P bioavailability}

From a eutrophication perspective, not all $P$ fractions are readily available for biological uptake (Ekholm, 1998; Li and Brett, 2015). Algal bioavailability of sRP in water is significantly higher compared to sNRP and pP fractions (Button, 1985; Ekholm, 1998; Lean, 1973; Reynolds and Davies, 2001). Laboratory algae growth studies have shown that the SRP fraction can be completely removed from water within hours (Button, 1985; Lean, 1973). Studies of Lake Erie tributaries also show that most sP is bioavailable to algae, whereas only about $30 \%$ of the $\mathrm{pP}$ fraction is bioavailable; thus, even in cases where $\mathrm{pP}$ dominates TP loading (e.g., major Ohio tributaries to Lake Erie), sRP often contributes more bioavailable $P$ (Baker et al., 2014). The bioavailability of the sRP fraction, and the fact that it is often the dominant form of $\mathrm{P}$ in wastewater, has made it the primary target for $\mathrm{P}$ monitoring and removal from wastewater (Ekholm, 1998; Rittmann et al., 2011). However, some studies have shown that the recalcitrant fractions (sNRP and pP) can also lead to cyanobacteria and algal growth (Monbet et al., 2009; Sañudo-Wilhelmy, 2006). Qin et al. (2015) showed that up to 75\% of sOP from the effluent of two tertiary wastewater 
treatment plants (filtration and activated carbon adsorption) was bioavailable for algae growth within a 14-day period. The long-term fate of these SNRP and $\mathrm{pP}$ fractions released in environmental waters is not yet known. Natural processes, e.g., enzymatic hydrolysis (phosphatase) and photolysis, may degrade even the most recalcitrant $P$ fractions, converting them to more bioavailable forms. Thus, all $P$ fractions should be considered relevant targets for removal strategies implemented in water to limit eutrophication risks.

\subsection{Removal and recovery of $P$}

The different $\mathrm{P}$ fractions and compositions behave differently with respect to removal and recovery. For example, while inorganic $P$ is removed reasonably well by most advanced treatment systems, OP commonly passes through (Mayer et al., 2016; Venkatesan et al., 2018). All existing removal processes rely on the extraction of $\mathrm{P}$ solids (De-Bashan and Bashan, 2004). For example, $\mathrm{pP}$ is amenable to direct removal via physical separation processes, while $\mathrm{SP}$ is converted into a solid phase (via, e.g., biological uptake, adsorption, or precipitation) to enable efficient separation. Regardless of the approach, $\mathrm{P}$ recoverability is enhanced by conversion of the NRP fraction to the more readily reusable RP form.

Conventional activated sludge and enhanced biological phosphorus removal (EBPR) wastewater treatment plants remove $\mathrm{P}$ using a combination of biological accumulation and physical/chemical separation techniques (Henze et al., 2008). Activated sludge plants rely heavily on tertiary physical/chemical processes (incorporating, e.g., granular or membrane filtration, coagulation, flocculation, or adsorption) to remove the majority of $\mathrm{P}$ (Neethling et al., 2010). To more specifically target $\mathrm{P}$ removal, EBPR plants modify conventional activated sludge to foster the growth of polyphosphate accumulating organisms (PAOs), which can accumulate significantly higher amounts of $P$ (>15\% P per dry cell weight compared to <3\% for typical cells) (Crocetti et al., 2000; Henze et al., 2008; Seviour et al., 2003). While more P can be concentrated in the microbial cells and removed in the secondary sludge stream using EBPR, physical/chemical techniques may still be used for further polishing to facilitate compliance with low effluent TP standards (Stephens et al., 2004). The secondary effluents of activated sludge, and to a lesser extent, EBPR, will still have both particulate and soluble RP and NRP fractions (Neethling et al., 2013, Neethling et al., 2010; Stephens et al., 2004) that may be amenable to removal via tertiary physical/chemical treatment processes. Gu et al. (2011) observed $>93 \%$ removal of sRP, pRP and pAHP (i.e., pNRP) during secondary biological treatment in a full-scale EBPR plant. However, only $78 \%$ OP and <40\% sAHP (i.e., sNRP) were removed.

Tertiary physicochemical P removal techniques, including granular, micro-, or ultra-filtration; coagulation; flocculation; precipitation; ion exchange; and adsorption, are highly effective in removing RP and even some pNRP fractions (Neethling et al., 2010; USEPA, 2010). However, they do not effectively remove the sNRP fraction, which passes through unaffected in the effluent (USEPA, 2010). Gu et al. (2011) observed that tertiary treatment including chemical coagulation using $\mathrm{FeCl}_{3}$ followed by filtration at an EBPR plant effectively removed SRP, SAHP, and pOP, but was not as effective in removing pAHP and sOP. Though NRP typically makes up only a small fraction of influent wastewater TP (1-10\%), NRP (sNRP in particular) can lead to failures in meeting regulatory effluent standards (USEPA, 2010).

Similarly, the more recalcitrant sOP and pP fractions present a challenge for achieving ultra-low level TP goals in some environmental waters, e.g., the Florida Everglades (Ged and Boyer, 2013). Installation of adjacent wetlands significantly reduced SRP in the Everglades system, but this approach cannot effectively reduce sNRP (White et al., 2004). In an ongoing effort to achieve ultra-low TP concentrations 
in the Everglades, the George Barley Water Prize, launched in 2016, seeks innovative technologies able to remove $P$ directly from the environmental water. This effort is part of an integrated approach to $P$ management including source reduction, e.g., best management of agricultural runoff and enhanced wastewater treatment, as well as P removal from the sink itself - in the actual waters of the Everglades. Notably, the Barley Prize acknowledges the importance of 1) P removal directly from environmental waters, 2) OP removal, and 3) opportunities to recover value-added products ( $\mathrm{P}$ removal + recovery paradigm) (Everglades foundation, 2016; Macintosh et al., 2018). Accordingly, diverse P management portfolios of the future could increasingly consider $P$ removal (and possibly even $P$ recovery) from environmental waters as one viable strategy.

Apart from removing $\mathrm{P}$ to limit eutrophication, recovering $\mathrm{P}$ for reuse is also essential for satisfying increasing agricultural $\mathrm{P}$ demands. Ideally, the recovered $\mathrm{P}$ should be readily available for reuse with limited additional processing. For agricultural reuse, the most direct approach is land application of manure or biosolids. However, because of the wide variation in P concentrations; P bioavailability; crop nutrient needs; and the presence of organic matter, metals, toxic compounds, and pathogens, land

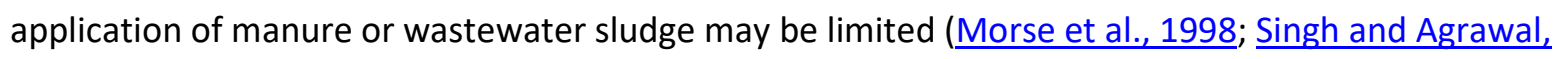
2008; USEPA, 1994).

Another option is to further process wastewater biosolids via incineration. Incineration reduces pathogen levels and attractiveness to vectors (rodents, flies, etc.) while retaining the $P$ nutrient content in the sewage sludge ash, which could potentially be land applied (Gerstle and Albrinck, 1982; USEPA, 1994). A key advantage of incineration is conversion of $P$ to reactive forms (complete conversion in the case of complete combustion). However, the bioavailability of the RP ranges by compound, and incinerated sewage sludge ashes are less bioavailable compared to dewatered sludge, meaning they are often less effective as fertilizers (Lemming et al., 2017). Sludge ash also retains heavy metals, which may provide incentive for further separation to recover a more specific $P$ product with greater bioavailability. Other considerations for implementation of incineration include energy costs and emissions of NOx and other gas-phase compounds (Gerstle and Albrinck, 1982; Werther and Ogada, 1999).

More selective $P$ recovery from water, wastewater, sludge, or ash can yield an inorganic chemical form that may provide a higher-value product that can replace or augment fertilizers derived from mined $P$. Precipitation of $\mathrm{P}$ as struvite (magnesium ammonium phosphate hexahydrate, $\mathrm{MgNH}_{4} \mathrm{PO}_{4} \cdot 6 \mathrm{H}_{2} \mathrm{O}$ ), a slow release fertilizer, is an increasingly common practice which serves as the basis of multiple commercially-

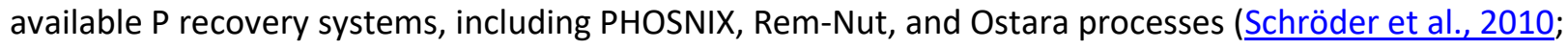
USEPA, 2010). Calcium phosphates such as hydroxylapatite, $\mathrm{Ca}_{5}\left(\mathrm{PO}_{4}\right)_{3}(\mathrm{OH})$, are alternative precipitates that can substitute for mined $\mathrm{P}$ as the raw material for production of high-grade fertilizers such as triple superphosphates (Morse et al., 1998). Regardless of the chemical composition of the product, $\mathrm{P}$ precipitation (i.e., the formation of pRP products) using metal cations such as $\mathrm{Ca}^{2+}$ and $\mathrm{Mg}^{2+}$ can only incorporate the SRP fraction. Thus, NRP must be converted to RP prior to recovery, e.g., hydrolysis of polyphosphate yields orthophosphate, which can then be recovered as struvite or hydroxylapatite (Yang et al., 2017).

\subsection{Can we capitalize on conversion of NRP?}

Various $P$ fractions behave differently with respect to removability/recoverability, yet to effectively limit eutrophication risks and substantially satisfy anthropogenic $P$ demands, consideration of all options for P removal/recovery, including NRP (sNRP, in particular), is imperative. This extends to capitalizing on 
opportunities at a variety of scales and from a variety of flows (e.g., animal, municipal, and industrial wastewater; environmental waters and agricultural runoff; and organic and industrial waste) (Mayer et al., 2016). The diversity in anthropogenic $P$ flows in global food production, illustrated in Fig. 1 , highlights the importance of $P$ removal and recovery strategies capable of addressing both point (e.g., sewage) and non-point (e.g., agriculture runoff) sources to move toward effectively closing the anthropogenic $\mathrm{P}$ loop. The composition and structure of $\mathrm{P}$ compounds in each fraction, and their relative magnitudes, can vary significantly depending on geographic location, environmental conditions, agricultural practices, and types of wastewater. A considerable proportion of the TP observed in both point and non-point sources consists of NRP (Fig. 1), and is currently not targeted for recovery. Thus, technologies capable of converting NRP to the more readily recoverable RP form while operating in low and high flow conditions, and variable water quality matrices are necessary for a circular P economy (Childers et al., 2011).

\section{Potential routes for NRP conversion}

In this section, we identify and assess strategies for improving P management by converting NRP in water, wastewater, and sludge matrices to RP forms amenable for subsequent recovery and reuse as Prich products. Conversion mechanisms and the related biological, physical, thermal, and chemical processes of potential relevance to $\mathrm{P}$ conversion applications are critically evaluated. This addresses a major gap in the literature as there are very few assessments of technologies specifically targeting conversion of NRP in water, wastewater, or sludge (and the majority of these existing assessments focus solely on sludge solubilization). Thus, we focus on identifying a suite of potential technologies such that future research can directly establish NRP conversion efficacy across various water matrices.

\subsection{Mechanisms of NRP conversion}

Conversion of NRP to RP requires disruption of bonds in complex NRP compounds. The primary classes of $\mathrm{P}$ bonds of interest include phosphoester $(\mathrm{P}-\mathrm{O}-\mathrm{C})$, phosphoanhydride $(\mathrm{P}-\mathrm{O}-\mathrm{P})$, and direct $\mathrm{P}-\mathrm{X}$ (where $X$ is an electronegative group such as carbon, sulfur, nitrogen or fluorine). Naturally forming inorganic polyphosphates (pyro-, tri-, meta-, etc.) and organic mono- and polyphosphates (e.g., glycerol phosphate, ATP, DNA, etc.) are non-reactive and typically contain phosphoester and/or phosphoanhydride bonds (Butusov and Jernelöv, 2013; Miller et al., 1969; Strauss and Day, 1967; Strauss and Krol, 1967; Strauss and Treitler, 1956; Thilo and Wieker, 1961). Direct P-X bonds are more commonly present in synthetic organophosphorus compounds (e.g., glyphosate, zinc dialkyldithiophosphates, cyclophosphamide, sarin, etc.) (Doong and Chang, 1997; Singh and Walker, 2006). Cleavage of these bonds may proceed via hydrolysis (nucleophilic substitution) or redox reactions.

The hydrolysis of phosphoesters and phosphoanhydrides is exothermic, making these bonds readily susceptible to hydrolytic scission, either enzymatically (e.g., by phosphatase) or chemically mediated (Fig. 6). The half-lives of hydrolysis reactions in environmental waters have been reported to range from 4 to $220 \mathrm{~d}$ (up to $7000 \mathrm{~d}$ in sterile water), versus $0.5 \mathrm{~d}$ for hydrolysis of pyrophosphate in domestic sewage (AWWA, 1970). The rate of hydrolysis increases with temperature and in acid/alkali pH conditions (Butusov and Jernelöv, 2013; Miller et al., 1969; Strauss and Dav, 1967; Strauss and Krol, 1967; Strauss and Treitler, 1956; Thilo and Wieker, 1961). The P-C bonds in organophosphorus compounds are more recalcitrant than the ester and anhydride bonds; however some studies have 
reported cleavage of $\mathrm{P}-\mathrm{O}$ and $\mathrm{P}-\mathrm{S}$ bonds via alkali or enzymatic hydrolysis (by, e.g., phosphonoacetate hydrolase) and oxidation (Costas et al., 2001; Doong and Chang, 1997; Dyguda-Kazimierowicz et al., 2014; Singh and Walker, 2006; Theriot and Grunden, 2011).

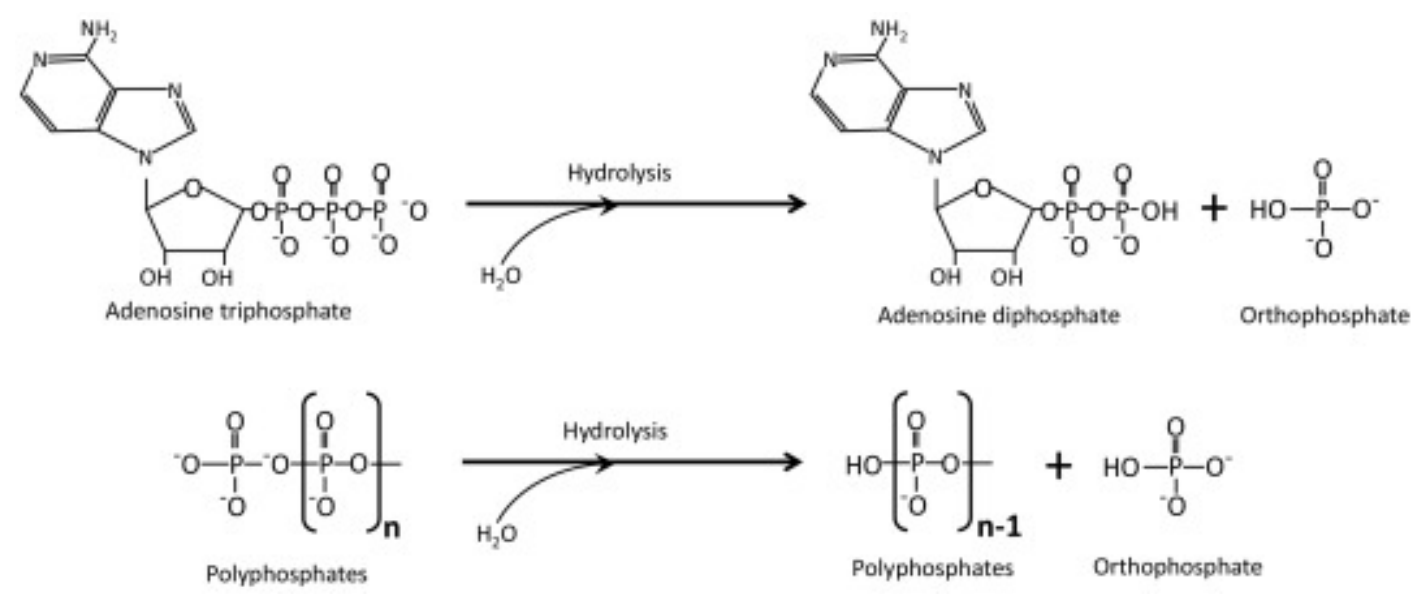

Fig. 6. Examples of non-reactive phosphorus (NRP) conversion to reactive $P$ (RP, also known as orthophosphate). The reactions illustrate hydrolysis of the phosphoanhydride $(\mathrm{P}-\mathrm{O}-\mathrm{P})$ bonds in organic adenosine triphosphate (ATP) (top) and inorganic polyphosphate (bottom).

In biological systems, $\mathrm{P}$ is widely reported as a redox conservative element, with biochemical reactions largely consisting of the formation and hydrolysis of phosphoester bonds. Phosphoesters certainly play a critical role in biochemistry, and $P$ is principally present in the fully oxidized +5 valence state in living systems; however, both natural and xenobiotic reduced $\mathrm{P}$ compounds may also play a role (Costas et al., 2001). If present, trivalent $P$ is easily oxidized. Moreover, when present in complex organophosphorus structures, NRP may convert to RP, or at least convert to a form more readily available for hydrolytic conversion, as oxidants break down densely conjugated aromatic organic matter.

Based on these mechanisms, potential NRP conversion technologies include biological, physical, thermal, and chemical operations that initiate and/or accelerate hydrolysis or redox reactions. However, there is a paucity of information on such processes for the purpose of NRP conversion. To date, technologies have been primarily investigated for the purpose of solubilizing thickened wastewater sludge streams with a focus on sludge dewatering, nutrient release, and improving digestion.

Accordingly, we critically review the performance of potential NRP conversion technologies applied to sludge for the purpose of improved residuals management. However, in principle, these approaches may also be applied for the specific objective of converting NRP to the more readily recoverable RP form. Moreover, this can be accomplished in other streams including high-strength animal manure, slaughterhouse waste, and chemical (pesticide) manufacturing wastewater. Some of these approaches may also be applicable for converting NRP in high flow, low strength waters, e.g., domestic wastewater, or even environmental waters at risk of eutrophication, e.g., high volume, low strength water bodies such as lakes and rivers.

\subsection{Biological P conversion}

Sludge fermentation technologies such as waste activated sludge stripping to remove accumulated phosphorus (WASSTRIP) and PhoStrip are common, commercially-available biological P conversion processes that have been applied at full-scale (Kroiss et al., 2011). These processes harness PAOs' ability 
to hydrolyze and release accumulated polyphosphates in an anaerobic environment in exchange for a carbon substrate (Levin and Shapiro, 1965). They involve retaining the sludge stream in an anaerobic "stripper" tank and can also include addition of acetic acid or diversion of the influent stream to stimulate polyphosphate release (Van Loosdrecht et al., 1997). The PhoStrip process has been successfully applied to release up to $67 \%$ P from both activated and EBPR sludge (Van Loosdrecht et al., 1997). However, a large fraction of the accumulated $P$ is retained in the sludge, including almost all OP (Levin and Shapiro, 1965). Large amounts of extra chemicals (acids for neutralization) may be needed as the water in the stripper tank can contain high alkalinity and $\mathrm{pH}(>9)$, which can hamper subsequent removal/recovery via precipitation (Van Loosdrecht et al., 1997; Wang et al., 2005). Sludge fermentation processes induce PAOs to release accumulated polyphosphate, making it available for hydrolysis. Therefore, they are only applicable in polyphosphate-rich EBPR wastewater treatment scenarios, and they are not able to solubilize other NRP fractions.

Anaerobic digestion is a well-established process for treatment of animal waste and waste activated and EBPR sludge. It uses anaerobic conversion of organic compounds to produce methane energy, while also releasing organically-bound $\mathrm{P}$ via hydrolysis, making the $\mathrm{P}$ available for recovery (Battistoni et al., 1997; Carey et al., 2016; Carrère et al., 2010; Huchzermeier and Tao, 2012; Peccia and Westerhoff, 2015; Rittmann et al., 2011; Uysal et al., 2010; Zeng and Li, 2006). Specific studies focused on the conversion of NRP to RP via anaerobic digestion of high-strength organic waste streams are currently lacking, warranting further research. Nonetheless, this combination of simultaneous nutrient and energy recovery potential can make anaerobic digestion a very attractive option. $\mathrm{P}$ recovery via struvite precipitation has been demonstrated from anaerobically digested sewage sludge and animal manure effluent streams (Battistoni et al., 1997; Huchzermeier and Tao, 2012; Uysal et al., 2010; Zeng and Li, 2006). Similarly, two-phase anaerobic digestion (with a pre-acidogenic phase at pH 6 or lower) demonstrated release of up to $60-90 \%$ of pP from pig manure (Piveteau et al., 2017). In this small-scale study, the $P$ was released as SRP, amenable to struvite recovery. However, the presence of $P$ during anaerobic digestion can also cause substantial economic and technical problems. Release of $\mathrm{P}$ in the

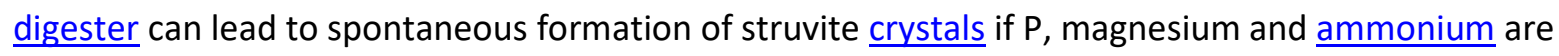
present in sufficient concentrations (Le Corre et al., 2009; Qureshi et al., 2006). This can cause scaling of the reactor vessels, pipes, and pumps, leading to extensive operation and maintenance costs (Marti et al., 2008; Ohlinger et al., 1998). For this reason, P may be removed from the waste stream prior to anaerobic digestion.

Other biological treatments have been investigated as options to improve sludge handling and/or anaerobic digestion performance (Ariunbaatar et al., 2014; Carrère et al., 2010), including aerobic (composting, micro-aeration), anaerobic (thermophilic digestion), and enzymatic (lysozymes, protease, lipase, and cellulose) pre/co-treatment techniques (Blonskaja et al., 2003; Burgess and Pletschke, 2008; Lim and Wang, 2013; Melamane et al., 2007; Mshandete et al., 2005; Muthangya et al., 2009; Riau et al., 2012; Sung and Santha, 2001; Wang and Zhao, 2009). Although these biological treatments are expected to release $\mathrm{P}$ via breakdown of complex organic material, no specific information on nutrient solubilization or NRP conversion was found in the literature. Thus, evaluations specifically targeting $P$ release potential are important to consider in future studies. 


\subsection{Physical P release}

Physical disintegration treatments release cellular materials from sludge flocs into water (Carrère et al., 2010; Elliott and Mahmood, 2012). A range of physical disintegration techniques such as liquid shearing (collision plate and high pressure homogenizer) and grinding/cutting processes (macerator and deflaker) have been applied to high solids streams to improve biodegradability for subsequent anaerobic treatment (Ariunbaatar et al., 2014; Carrère et al., 2010). These approaches have been used to improve solids destruction, biogas production, nutrient solubilization, sludge dewaterability, and reduce sludge volume and foaming (Carrère et al., 2010). Naturally, improvement in cell destruction increases the release of intracellular compounds, including nutrients like nitrogen and P. For example, Müller (2000) observed a threefold increase in supernatant $\mathrm{P}$ concentrations after disintegration by high-pressure homogenization (80 MPa). Similarly, Kampas et al. (2007) observed a maximum threefold increase in sP after 15 min pretreatment of an EBPR sludge with a deflaker. Once NRP is released from complex molecules, it can be more readily converted to RP via hydrolysis, and subsequently recovered for reuse.

Relatively sophisticated sludge pretreatment technologies such as ultrasound and pulsed electric field (PEF) have been used for sludge disintegration and disinfection with advanced oxidation in small-scale studies (Khanal et al., 2007; Rittmann et al., 2008; Salerno et al., 2009); however, they are not currently used at large scales. Ultrasound treatment lyses cells and disrupts other particulate matter. Large soluble molecules are then degraded by two key mechanisms: cavitation, which occurs at low frequencies (20-40 kHz), and chemical oxidation due to the formation of hydroxyl radicals (HO.) at high frequencies (Carrère et al., 2010; Khanal et al., 2007; Tiehm et al., 2001). Wang et al. (2010) used $500 \mathrm{kWh} / \mathrm{m}^{3}$ high intensity ultrasound to treat an EBPR sludge sample, and observed $>60 \% \mathrm{P}$ release in $1 \mathrm{~h}, 80 \%$ of which was in the sRP form.

In PEF, high-voltage (>20 kV) electrical pulses (produced at rates of thousands per second) are applied, e.g., as a means of sludge disintegration or food sterilization (Rittmann et al., 2008; Salerno et al., 2009). The basic components of all cell membranes and walls (phospholipids/peptidoglycan) are charged and polar, making them susceptible to electric fields, thereby resulting in complete cell lysis during PEF (Min et al., 2007; Salerno et al., 2009). Choi et al. (2006) applied PEF at 19 kV, $110 \mathrm{~Hz}$ to waste activated sludge samples, and reported an increase in supernatant $\mathrm{P}$ by a factor of 2.3 .

\subsection{Thermal P conversion}

Thermal breakdown of organic compounds by application of heat at temperatures of 50 to $250{ }^{\circ} \mathrm{C}$ and pressure has been successfully applied to enhance sludge disintegration for improved sludge dewaterability and anaerobic digestion at large scales (Ariunbaatar et al., 2014; Bougrier et al., 2006; Carlsson et al., 2012; Carrère et al., 2010; Cesaro and Belgiorno, 2014; Haug et al., 1978; Tanaka and Kamiyama, 2002). The breakdown of complex organic matter during thermal hydrolysis simultaneously releases nutrients. Kuroda et al. (2002) released $90 \%$ of the organically-bound P by heating activated sludge to $70^{\circ} \mathrm{C}$ for $1 \mathrm{~h}$. $\mathrm{P}$ release increased with increasing temperature. Near complete $\mathrm{P}$ release was observed using $80^{\circ} \mathrm{C}$ treatment for $20 \mathrm{~min}$ ( $80 \%$ of the released P was in the AHP form), while $10 \mathrm{~min}$ treatment provided near complete removal at $90{ }^{\circ} \mathrm{C}(40 \%$ in the AHP form). Extended exposure to high temperatures $\left(70-90^{\circ} \mathrm{C}\right.$ ) can ostensibly hydrolyze and convert polyphosphate NRP to sRP (Kuroda et al., 2002).

Steam heating (heat transfer from steam) is typically applied in large-scale systems (Mottet et al., 2009); however, microwave heating (direct irradiation of sludge) has been shown to solubilize polymers in 
small-scale studies (Marin et al., 2010; Toreci et al., 2009). Microwave heating can be advantageous as the heating process can be precisely controlled and heat generation within the material is more uniform, both internally and on the surface, in comparison to conventional steam heating (Liao et al., 2005a). Liao et al. (2005a) reported up to $76 \%$ release of the TP in sewage sludge using microwave heating at $170^{\circ} \mathrm{C}$ for $5 \mathrm{~min}$. To date, effective thermal breakdown of polyphosphates to SRP has been demonstrated, whereas future studies evaluating the effect of heat on release of other NRP constituents are still needed.

\subsection{Acid/alkali P conversion}

Chemical treatment by means of strong acids and bases has been extensively investigated as an approach for solubilization of solids and large organic molecules (Carrère et al., 2010). However, literature reports of $\mathrm{P}$ release typically quantify sRP before and after treatment, making it difficult to ascertain whether the increase in SRP resulted from conversion of NRP or pRP. The PRP fraction, including divalent cation precipitates (e.g., calcium or magnesium phosphates), has been shown to be more susceptible to solubilization after acid treatment in comparison to alkali treatment. Specifically, Stark et al. (2006) observed $83 \%$ release of $\mathrm{Ca}^{2+}$ ions after $1 \mathrm{M} \mathrm{HCl}$ treatment, whereas only $0.19 \% \mathrm{Ca}^{2+}$ ions were released after $1 \mathrm{M} \mathrm{NaOH}$ treatment. Accordingly, it seems likely that acid treatment can convert both NRP and pRP to SRP, whereas alkali treatment primarily converts NRP to SRP.

Alkali treatment is effective, in order of sludge solubilization efficacy: $\mathrm{NaOH}>\mathrm{KOH}>\mathrm{Mg}(\mathrm{OH})_{2}$ and $\mathrm{Ca}(\mathrm{OH})_{2}$ ( $\mathrm{Kim}$ et al., 2003). Similarly, strong acids $\left(\mathrm{H}_{2} \mathrm{SO}_{4}, \mathrm{HCl}\right)$ can improve anaerobic digestibility of sludge and dairy manure (Devlin et al., 2011; jin et al., 2009). Acid/alkali treatments, including $\mathrm{NaOH}$; $\mathrm{HCl}$; citric acid; and microwave irradiation combined with $\mathrm{NaOH}, \mathrm{CaO}, \mathrm{H}_{2} \mathrm{SO}_{4}$, or $\mathrm{HCl}$, have also improved $P$ release ( $\underline{\text { jin et al., 2009; }}$ Mavinic and Koch, 2003; Stark et al., 2006). Approximately 2-4 fold increase in P solubilization was observed when treating sludge with $10 \mathrm{mM} \mathrm{HCl}$ or $\mathrm{NaOH}$ for $30 \mathrm{~h}$ (Mavinic and Koch, 2003). Microwave thermochemical sludge treatment at $120^{\circ} \mathrm{C}$ for $30 \mathrm{~min}$ with $0.07 \mathrm{~g}-\mathrm{NaOH} / \mathrm{g}$ manure and $0.75 \%$ vol/vol $\mathrm{HCl}$ released $20-30 \%$ of dairy manure $\mathrm{P}$ (Jin et al., 2009). Acid/alkali thermochemical treatment has increased solubilization efficiency $25-30 \%$ when using a microwave rather than a conventional oven heating source (Mavinic and Koch, 2003). In addition to sludge, acid/alkali treatment has been used to recover $\mathrm{P}$ from incinerated sludge residues. Stark et al. (2006) reported $87 \% \mathrm{P}$ release after treating incinerated sludge ash with $1 \mathrm{M} \mathrm{HCl}$ and $70 \% \mathrm{P}$ release using $1 \mathrm{M}$ $\mathrm{NaOH}$.

\subsection{Redox reactions: $P$ conversion using advanced oxidation processes}

As $P$ is most often present in the +5 valence state in water matrices, oxidation typically does not target $P$ bonds specifically. However, when NRP is locked in complex organic matrices, advanced oxidation can help to release this $\mathrm{P}$, making it available for hydrolytic conversion to $\mathrm{RP}$, or yielding recoverable sRP via complete oxidation.

Advanced oxidation processes (AOPs) are primarily defined as oxidation processes involving the generation of hydroxyl radicals $(\mathrm{HO} \cdot)$, which are the most powerful oxidizing species $\left(\mathrm{E}^{\circ}=2.80 \mathrm{~V}\right)$ after fluorine. Other strongly oxidizing radicals include sulfate radicals $\left(\mathrm{SO}_{4 *}{ }^{-}, \mathrm{E}^{\circ}=2.60 \mathrm{~V}\right)$, which serve as the basis for sulfate radical AOPs (SR-AOPs). These powerful, non-selective oxidizing agents can mineralize organic compounds to simple, relatively harmless molecules, e.g., carbon to carbon dioxide and $\mathrm{P}$ to phosphates or phosphoric acids (Parsons, 2004). A number of AOPs have been developed for water and wastewater treatment applications, as detailed in comprehensive reviews by Comninellis et al. (2008), 
Parsons (2004) and Poyatos et al. (2010). Some of the more commonly used AOPs in research or application include photochemical degradation processes $\left(\mathrm{UV} / \mathrm{O}_{3}, \mathrm{UV} / \mathrm{H}_{2} \mathrm{O}_{2}, \mathrm{X}-\mathrm{ray} / \mathrm{H}_{2} \mathrm{O}_{2}\right)$, photocatalysis $\left(\mathrm{TiO}_{2} / \mathrm{UV}\right.$, photo-Fenton), sonolysis (ultrasonication/ $\left.\mathrm{H}_{2} \mathrm{O}_{2}\right)$, chemical oxidation $\left(\mathrm{O}_{3} / \mathrm{H}_{2} \mathrm{O}_{2}, \mathrm{H}_{2} \mathrm{O}_{2} / \mathrm{Fe}^{2+}\right)$, and electrochemical processes (Poyatos et al., 2010; Wang and Xu, 2012). These processes have been successfully applied for the oxidation of a wide array of organic contaminants in water, including toxic and recalcitrant species (e.g., aromatic compounds, dyes, pharmaceuticals, and pesticides), microbes (e.g., coliform bacteria, Cryptosporidium, and viruses), and bulk organics (e.g., humic material, amino

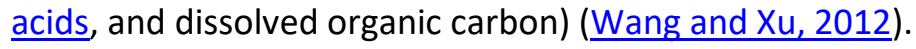

Several studies have also investigated AOPs for solubilizing organically-bound $\mathrm{P}$ in sludge. Researchers at the University of British Columbia evaluated the use of microwave-assisted $\mathrm{O}_{3}, \mathrm{H}_{2} \mathrm{O}_{2}$, and $\mathrm{O}_{3} / \mathrm{H}_{2} \mathrm{O}_{2}$ AOPs targeting $\mathrm{P}$ release from activated and EBPR sludge (Kenge et al., 2009;

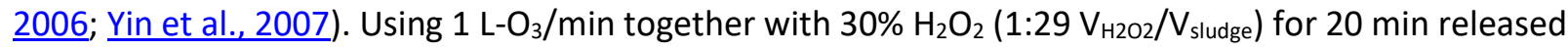
24-31\% TP from sludge. The addition of microwave heating to a temperature of $100{ }^{\circ} \mathrm{C}$ for $3 \mathrm{~min}$ improved $\mathrm{P}$ release by an additional $20 \%$ (Yin et al., 2007). Liao et al. (2005b) reported up to $84 \%$ release of TP from EBPR sludge using $30 \% \mathrm{H}_{2} \mathrm{O}_{2}\left(1: 20 \mathrm{~V}_{\mathrm{H} 2 \mathrm{O} 2} / \mathrm{V}_{\text {sludge }}\right)$ and microwave heating for $5 \mathrm{~min}$ at $170{ }^{\circ} \mathrm{C}$. Up to $95 \% \mathrm{P}$ release was reported from sewage sludge using $1 \mathrm{~L} / \mathrm{min}$ ozonation for 9 min followed by addition of $30 \% \mathrm{H}_{2} \mathrm{O}_{2}\left(6: 84 \mathrm{~V}_{\mathrm{H} 2 \mathrm{O} 2} / \mathrm{V}_{\text {sludge }}\right)$ and microwave heating to a temperature of $120{ }^{\circ} \mathrm{C}$ for $4 \mathrm{~min}$ (Yin et al., 2008). More than $90 \%$ of TP was released from wastewater sludge in 20 min using ultrasonication ( $320 \mathrm{kWh} / \mathrm{m}^{3}$ )-assisted Fenton oxidation ( $0.4 \mathrm{~g}-\mathrm{Fe}^{2+} / \mathrm{L} ; 0.5 \mathrm{~g}-\mathrm{H}_{2} \mathrm{O}_{2} / \mathrm{L}$ ) (Gong et al., 2015). These reports indicate that greater $\mathrm{P}$ release resulted with higher hydrogen peroxide concentration, higher temperatures, and/or duration of treatment.

Unlike other potential P conversion processes, several studies have reported the use of AOPs to degrade soluble organophosphorus pesticides (Badawy et al., 2006; Daneshvar et al., 2004; Farooq et al., 2003; Trebše and Arčon, 2003; Trebše and Franko, 2002). AOPs such as UV/ $\mathrm{H}_{2} \mathrm{O}_{2}$, Fenton, and photo-Fenton were able to degrade $50-70 \%$ of the organophosphorus compounds profenofos, diazinon, and fenitrothion in simulated dilute wastewaters ( $<2 \%$ solids, $50 \mathrm{mg} / \mathrm{L}$ organophosphorus concentration) (Badawy et al., 2006). Although the studies do not specify the extent of conversion of the organophosphorus compounds to SRP, the success of AOPs in degrading recalcitrant compounds warrants further investigation into their effectiveness at converting SNRP species to SRP to facilitate $P$ removal and recovery.

\section{Comparative assessment of $P$ conversion process applications}

Although NRP can account for a substantial proportion of the TP in some water, wastewater, and sludge matrices, it is not commonly targeted to enhance removal and recovery operations. To advance the circular P economy needed to both protect environmental waters and support global food production, future technologies must be assessed in terms of their ability to convert different compositions of NRP to the more readily recoverable reactive fraction across a range of water matrices.

\subsection{Conversion process comparison}

The data needed to perform a systematic comparison of NRP conversion methods in terms of their efficiencies, economic feasibility and environmental impacts does not yet exist, but is necessary for identifying an effective NRP conversion process for a given application. While quantitative technologyspecific comparisons are not yet feasible, we qualitatively compared the broad categories of conversion 
methods (biological, physical, thermal, and chemical) based on the limited literature reports of conversion potential reviewed here. This preliminary comparative evaluation of process potential to convert NRP in variable water, wastewater, and sludge matrices, as summarized in Table 1, was performed using inferences based on currently available sludge solubilization data.

Table 1. Preliminary qualitative comparison of categories of processes for NRP conversion.

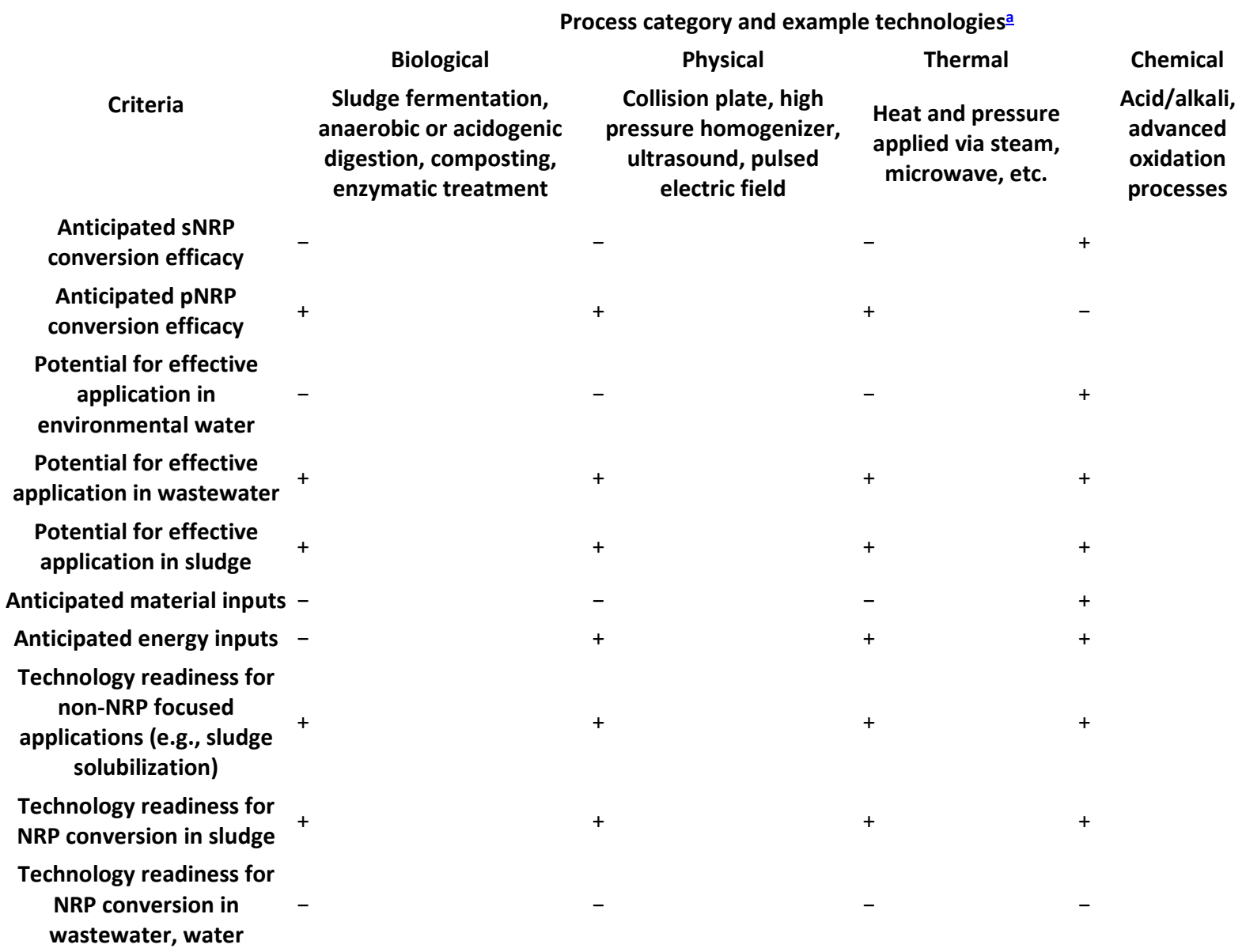

aQualitative ratings (+ represents high potential, - represents low potential) based on literature reports of process performance, primarily available for sludge solubilization applications.

Mechanical, biological and thermal technologies may be applied to sludge/manure streams to potentially enhance $P$ recoverability. Mechanical pretreatment techniques such as liquid shear, lysis, centrifugation, and bar milling are simple, cheap and odorless (Ariunbaatar et al., 2014; Carrère et al., 2010). They are primarily designed to break down large particles into smaller ones, which may release $P$ from cellular material via lysis. Similarly, biological treatments such as sludge fermentation (e.g., WASSTRIP and PhoStrip) and traditional or pre-acidogenic phase anaerobic digestion may improve pNRP release in high $\mathrm{P}$ strength sludge/manure streams. However, mechanical and biological technologies are unlikely to be effective for dilute streams or in converting SNRP. Although future studies are needed, high intensity ultrasonication, PEF and thermal pretreatment may be effective for converting both sNRP and pNRP; however, high energy inputs may be a challenge for dilute waters (Ariunbaatar et al., 2014). 
Acid/alkali and AOP conversion technologies are effective in solubilizing $P$ in high strength sludge streams, and converting soluble, colloidal, and particulate NRP fractions to RP. However, these processes oftentimes rely on relatively high inputs of chemicals and/or energy, and must be evaluated for the specific purpose of $\mathrm{P}$ conversion before their relevance in various matrices can be assessed. Additional considerations include that acid/alkali treatments often have issues regarding odors, $\mathrm{pH}$ control, and formation of toxic/inhibitory byproducts (Ariunbaatar et al., 2014; Carrère et al., 2010). Likewise, AOP systems may lead to incomplete oxidation, the byproducts of which must be evaluated. AOPs do have the potential for providing greater NRP conversion; however, the chemical and/or energy inputs needed for this application are likely a major hurdle for NRP conversion applications.

\subsection{Relevance of $P$ conversion processes to applications beyond sludge solubilization}

To the authors' knowledge, there are currently no reports of $\mathrm{P}$ conversion technologies applied to water flows characterized by higher volumetric flowrates and/or lower $\mathrm{P}$ concentrations in comparison to sludge, e.g., secondary effluent from municipal wastewater treatment plants or environmental surface waters. Even in controlled lab environments, reports of conversion of specific NRP species are uncommon. However, to better satisfy ultra-low $P$ removal guidelines while taking full advantage of opportunities to close the anthropogenic $P$ cycle by removing and recovering $P$ from a wide variety of streams, such $\mathrm{P}$ conversion processes may play an important role, and deserve further exploration in future studies.

To inform comparisons of the applicability of different potential conversion technologies across a range of water matrices, both $\mathrm{P}$ concentration and composition must be considered. While the relative fraction of NRP to RP varies across these matrices, environmental waters, wastewaters, and manures tend to have higher SRP fractions in comparison to sludge (ig. 5). As discussed in Section 2.3, TP concentrations vary widely both spatially and temporally, but typically follow the trend manure $>$ sludge $>$ wastewater $>$ environmental waters. Accordingly, P removal and recovery strategies are most often implemented in applications aligned with this hierarchical order. However, as noted in this article, there may be needs and opportunities for $\mathrm{P}$ removal/recovery across an array of water matrices in the future, not just in sludge, making it important to consider a range of options for NRP conversion.

Fig. 3 illustrates several examples of P species from each of the major P fractions. Each of these compounds could potentially be present in all of the water and sludge matrices, albeit at different concentrations. For example, both sludge and environmental waters are likely to contain cellular $P$ (classified as pNRP), but higher concentrations would be expected in sludge as opposed to environmental waters. Based on the overlap of $\mathrm{P}$ species ostensibly present in each matrix, the potential NRP conversion technologies reviewed here (current reports of which focus primarily on sludge) may also be relevant in other matrices. Key considerations for technology implementation will include the influence of other competing constituents (e.g., organics, which are higher in sludge/manure), P content (e.g., lower levels of $P$ in environmental waters may lead to lower per unit conversion efficacy), and ease of implementation (e.g., application in diffuse settings such as environmental waters is likely more technically challenging and less cost effective compared to concentrated $\mathrm{P}$ matrices).

Given these considerations, chemical conversion processes (acid/alkali and AOPs) are likely to offer potential for conversion of NRP in low-strength waters to SRP forms amenable to recovery. While 
additional research is needed to evaluate efficacy of these methods for NRP conversion, the use of acid or oxidant treatment for conversion of NRP is the basis for standard TP measurements (APHA, 2012), lending credence to this approach. Briefly, Standard Method $4500 f$ involves sample pretreatment using a strong acid (nitric, sulfuric and perchloric acid) or an oxidant (persulfate) to convert AHP and OP species to a reactive orthophosphate form. The RP can then be measured using the ascorbic acid method. The same principle of conversion using hydrolysis or oxidation of NRP can be applied to facilitate $\mathrm{P}$ removal/recovery from environmental waters, wastewater, or sludge. However, additional research is needed to specifically establish the efficacy of conversion in water matrices in terms of percent $P$ relative to energy and chemical inputs.

\section{Conclusions and future research needs}

Capturing the lost $\mathrm{P}$ is essential for the circular $\mathrm{P}$ economy by abating concerns regarding depleting mineral $\mathrm{P}$ reserves and increasing $\mathrm{P}$-based pollution. Hence, it is important to recognize the total potential for removal and recovery of all of the lost $P$ fractions, the non-reactive portion of which has historically been neglected. Here, we contend that the NRP fraction can no longer be ignored based on its potentially significant role in point and nonpoint source $P$ regulations, its longer-term eutrophication potential in the environment, and its relative contribution to maximizing total $P$ recovery.

Most P discharge regulations are defined on a TP basis rather than SRP as environmental processes eventually convert the NRP in lakes and rivers to reactive (and more biologically available) P forms. Thus, to protect environmental waters and comply with increasingly lower effluent TP discharge limits, considering removal of the largely inaccessible NRP fraction advances the status quo of $\mathrm{P}$ management strategies. To further expand the portfolio of viable $\mathrm{P}$ management opportunities, the potential for $\mathrm{P}$ removal to ultra-low levels in wastewater, sludge, and even in-stream intervention in sensitive environmental waters should be leveraged. Moreover, it is prudent to consider how conversion of NRP to RP can enhance P recovery to supplement natural, non-renewable P reserves. Such an evaluation does not currently exist in the literature, making it essential to provide critical insights focused on the current status of NRP conversion and future research advancements needed to enhance $P$ removal and recovery.

This critical review offers the first step in addressing uncertainties related to NRP: what is the big deal and what can we do about it? We offer a forward-looking assessment of 1) the presence and role of NRP in environmental water, wastewater, and sludge matrices; and 2) NRP conversion mechanisms and the associated strategies for improving P management by converting the NRP to RP forms amenable to subsequent recovery and reuse as P-rich products. Through the review, we highlight NRP-related research gaps that must be addressed to maximize the capture of all lost $P$, including NRP (sNRP, in particular), by capitalizing on a range of opportunities at a variety of scales and from a variety of flows, including environmental waters, wastewater, and sludge.

The meta-analysis performed here included over 20,000 data points on $\mathrm{P}$ quantity and $\mathrm{P}$ form, and clearly showed that $\mathrm{P}$ quantity and form varies by water matrix, and is not always present in the more readily removable/recoverable reactive form. Beyond TP and SRP data, there is a need for greater quantification and characterization of other $P$ fractions and specific $P$ constituents across water matrices. Developing a better understanding of NRP composition and variability amongst and within water matrices would help to identify target streams for NRP conversion and enhanced $P$ 
removal/recovery potential. Additionally, further establishing the physical/chemical properties (organic/inorganic, soluble/particulate, linear/aromatic, long/short chain, etc.) of the NRP fractions would assist in selecting and evaluating appropriate NRP conversion technologies in future studies.

While NRP can contribute substantially to overall TP in environmental water, wastewater, and sludge, no technologies have been implemented to specifically target recovery of this fraction. Mechanisms of NRP conversion include hydrolysis and redox pathways. Potential NRP conversion technologies include biological, physical, thermal, and chemical operations that initiate and/or accelerate these reactions. To date, technologies have been primarily investigated for the purpose of solubilizing thickened wastewater sludge streams with a focus on sludge dewatering, nutrient release, and improving digestion. Accordingly, we critically reviewed the performance of potential NRP conversion technologies applied to sludge for the purpose of improved residuals management. In principle, these approaches may also be applied for the specific objective of converting NRP to the more readily recoverable RP form. Moreover, this can be accomplished in other streams including high-strength animal manure, slaughterhouse waste, and chemical (pesticide) manufacturing wastewater. In future research, these applications must be critically evaluated, including establishing P conversion, removal, and recovery efficacy across matrices of interest; elucidating the mechanistic basis for NRP conversion and the resulting products; assessing the role of water quality and operational parameters on process performance; and analyzing costs, environmental impacts, and the feasibility of implementation (e.g., techno-economic analysis). While many questions remain, the conversion of NRP to RP may offer a feasible option for enhancing $P$ removal and recovery, and is a topic of great interest as we move toward a circular $\mathrm{P}$ economy.

\section{Acknowledgements}

This work was supported in part by the National Science Foundation (NSF) under CAREER Award 1554511 and the NSF Water Equipment and Policy Center (WEP) at Marquette University under Grant No. 0968844. BKM acknowledges support from the NSF Research Coordination Network Science, Engineering, and Education for Sustainability Program (Award 1230603). The authors are grateful for Dr. Anthony Kappell's assistance with the PCA analysis. All opinions expressed here are the authors' and do not necessarily reflect the views of NSF.

\section{References}

American Public Health Association (APHA); American Waterworks Association (AWWA); Water Environment Federation (WEF), 2012 American Public Health Association (APHA); American Waterworks Association (AWWA); Water Environment Federation (WEF) Standard Methods for the Examination of Water and Wastewater, Standard Methods McGraw-Hill Companies, Inc., New York, NY, USA (2012) (doi:ISBN 9780875532356)

Ariunbaatar et al., 2014 J. Ariunbaatar, A. Panico, G. Esposito, F. Pirozzi, P.N.L. Lens Pretreatment methods to enhance anaerobic digestion of organic solid waste Appl. Energy, 123 (2014), pp. 143-156, 10.1016/i.apenergy.2014.02.035

AWWA, 1970 AWWA Chemistry of nitrogen and phosphorus in water Am. Water Work. Assoc., 62 (1970), pp. 127-140 
Aydin et al., 2010 I. Aydin, F. Aydin, C. Hamamci Phosphorus speciation in the surface sediment and river water from the Orontes (Asi) River, Turkey Water Environ. Res., 82 (2010), pp. 2265-2271, $10.2307 / 29763487$

Badawy et al., 2006 M.I. Badawy, M.Y. Ghaly, T.A. Gad-Allah Advanced oxidation processes for the removal of organo - phosphorus pesticides from wastewater Desalination, 194 (2006), pp. 166175, 10.1016/i.desal.2005.09.027

Baker et al., 2014 D.B. Baker, R. Confesor, D.E. Ewing, L.T. Johnson, J.W. Kramer, B.J. Merryfield Phosphorus loading to Lake Erie from the Maumee, Sandusky and Cuyahoga rivers: the importance of bioavailability J. Great Lakes Res., 40 (2014), pp. 502-517, 10.1016/i.jglr.2014.05.001

Battistoni et al., 1997 P. Battistoni, G. Fava, P. Pavan, A. Musacco, F. Cecchi Phosphate removal in anaerobic liquors by struvite crystallization without addition of chemicals: preliminary results Water Res., 31 (1997), pp. 2925-2929, 10.1016/S0043-1354(97)00137-1

Blonskaja et al., 2003 V. Blonskaja, A. Menert, R. Vilu Use of two-stage anaerobic treatment for distillery waste Adv. Environ. Res., 7 (2003), pp. 671-678, 10.1016/S1093-0191(02)00038-2

Bougrier et al., 2006 C. Bougrier, C. Albasi, J.P. Delgenès, H. Carrère Effect of ultrasonic, thermal and ozone pre-treatments on waste activated sludge solubilisation and anaerobic biodegradability Chem. Eng. Process. Process Intensif., 45 (2006), pp. 711-718, 10.1016/j.cep.2006.02.005

Bravo et al., 2017 H.R. Bravo, H. Bootsma, B. Khazaei Modeling the Transport and Fate of Phosphorus From a Point Source in the Lake Michigan Nearshore Zone 6865 (2017), pp. 5172-5179

Burgess and Pletschke, 2008 J.E. Burgess, B.I. Pletschke Hydrolytic enzymes in sewage sludge treatment: a mini-review WaterSA, 34 (2008), pp. 343-350

Button, 1985 D.K. Button Kinetics of nutrient-limited transport and microbial growth Microbiol. Rev., 49 (1985), pp. 270-297

Butusov and Jernelöv, 2013 M. Butusov, A. Jernelöv Phosphorus in the Organic Life: Cells, Tissues, Organisms Springer, New York, NY (2013), pp. 13-17, 10.1007/978-1-4614-6803-5 2

Cade-Menun et al., 2006 B.J. Cade-Menun, J.A. Navaratnam, M.R. Walbridge Characterizing dissolved and particulate phosphorus in water with 31P nuclear magnetic resonance spectroscopy Environ. Sci. Technol., 40 (2006), pp. 7874-7880, 10.1021/es061843e

Carey et al., 2016 D.E. Carey, Y. Yang, P.J. McNamara, B.K. Mayer Recovery of agricultural nutrients from biorefineries Bioresour. Technol., 215 (2016), pp. 186-198, 10.1016/i.biortech.2016.02.093

Carlsson et al., 2012 M. Carlsson, A. Lagerkvist, F. Morgan-Sagastume The effects of substrate pretreatment on anaerobic digestion systems: a review Waste Manag., 32 (2012), pp. 1634-1650, 10.1016/j.wasman.2012.04.016

Carrère et al., 2010 H. Carrère, C. Dumas, A. Battimelli, D.J. Batstone, J.P. Delgenès, J.P. Steyer, I. Ferrer Pretreatment methods to improve sludge anaerobic degradability: a review J. Hazard. Mater., 183 (2010), pp. 1-15, 10.1016/j.jhazmat.2010.06.129

Cesaro and Belgiorno, 2014 A. Cesaro, V. Belgiorno Pretreatment methods to improve anaerobic biodegradability of organic municipal solid waste fractions Chem. Eng. J. (2014), 10.1016/i.cej.2013.11.055

Childers et al., 2011 D.L. Childers, J. Corman, M. Edwards, J.J. Elser Sustainability challenges of phosphorus and food: solutions from closing the human phosphorus cycle Bioscience, 61 (2011), pp. 117-124, 10.1525/bio.2011.61.2.6 
Choi et al., 2006 H. Choi, S.-W. Jeong, Y. Chung Enhanced anaerobic gas production of waste activated sludge pretreated by pulse power technique Bioresour. Technol., 97 (2006), pp. 198-203, 10.1016/i.biortech.2005.02.023

Comninellis et al., 2008 C. Comninellis, A. Kapalka, S. Malato, S.A. Parsons, I. Poulios, D. Mantzavinos Advanced oxidation processes for water treatment: advances and trends for R\&D J. Chem. Technol. Biotechnol., 83 (2008), pp. 769-776, 10.1002/jctb.1873

Cordell and White, 2014 D. Cordell, S. White Life's bottleneck: sustaining the world's phosphorus for a food secure future Annu. Rev. Environ. Resour., 39 (2014), pp. 161-188, 10.1146/annurevenviron-010213-113300

Cordell et al., 2009 D. Cordell, J.-O. Drangert, S. White The story of phosphorus: global food security and food for thought Glob. Environ. Chang., 19 (2009), pp. 292-305, 10.1016/j.gloenvcha.2008.10.009

Correll, 1999 D.L. Correll Phosphorous: a rate limiting nutrient in surface waters Poult. Sci. (1999), pp. 674-682

Costas et al., 2001 A.M.G. Costas, A.K. White, W.W. Metcalf Purification and characterization of a novel phosphorus-oxidizing enzyme from pseudomonas stutzeri WM88 J. Biol. Chem., 276 (2001), pp. 17429-17436, 10.1074/ibc.M011764200

Crocetti et al., 2000 G.R. Crocetti, P. Hugenholtz, P.L. Bond, A. Schuler, J. Keller, D. Jenkins, L.L. Blackall Identification of polyphosphate-accumulating organisms and design of $16 \mathrm{~S}$ rRNA-directed probes for their detection and quantitation Appl. Environ. Microbiol., 66 (2000), pp. 1175-1182, 10.1128/AEM.66.3.1175-1182.2000

Daneshvar et al., 2004 N. Daneshvar, M.J. Hejazi, B. Rangarangy, A.R. Khataee Photocatalytic degradation of an organophosphorus pesticide Phosalone in aqueous suspensions of titanium dioxide J. Environ. Sci. Health B, 39 (2004), pp. 285-296, 10.1081/PFC-120030242

De-Bashan and Bashan, 2004 L.E. De-Bashan, Y. Bashan Recent advances in removing phosphorus from wastewater and its future use as fertilizer (1997-2003) Water Res., 38 (2004), pp. 4222-4246, 10.1016/j.watres.2004.07.014

Devlin et al., 2011 D.C. Devlin, S.R.R. Esteves, R.M. Dinsdale, A.J. Guwy The effect of acid pretreatment on the anaerobic digestion and dewatering of waste activated sludge Bioresour. Technol., 102 (2011), pp. 4076-4082, 10.1016/j.biortech.2010.12.043

Dodds et al., 2009 W.K. Dodds, W.W. Bouska, J.L. Eitzmann, T.J. Pilger, K.L. Pitts, A.J. Riley, J.T. Schloesser, D.J. Thornbrugh Eutrophication of U.S. freshwaters: analysis of potential economic damages Environ. Sci. Technol., 43 (2009), pp. 12-19, 10.1021/es801217q

Doong and Chang, 1997 R.-A. Doong, W.-H. Chang Photoassisted titanium dioxide mediated degradation of organophosphorus pesticides by hydrogen peroxide J. Photochem. Photobiol. A Chem., 107 (1997), pp. 239-244, 10.1016/S1010-6030(96)04579-0

Dueñas et al., 2003 J.F. Dueñas, J.R. Alonso, À.F. Rey, A.S. Ferrer Characterisation of phosphorous forms in wastewater treatment plants J. Hazard. Mater., 97 (2003), pp. 193-205, 10.1016/S03043894(02)00260-1

Dyguda-Kazimierowicz et al., 2014 E. Dyguda-Kazimierowicz, S. Roszak, W.A. Sokalski Alkaline hydrolysis of organophosphorus pesticides: the dependence of the reaction mechanism on the incoming group conformation J. Phys. Chem. B, 118 (2014), pp. 7277-7289, 10.1021/ip503382i 
Egle et al., $2015 \mathrm{~L}$. Egle, H. Rechberger, M. Zessner Overview and description of technologies for recovering phosphorus from municipal wastewater Resour. Conserv. Recycl., 105 (2015), pp. 325-346, 10.1016/i.resconrec.2015.09.016

Ekholm, $1998 \mathrm{P}$. Ekholm Algal-available phosphorus originating from agriculture and municipalities Monographs of the Boreal Environment Research, Finnish Environment Institute (1998)

Elliott and Mahmood, 2012 A. Elliott, T. Mahmood Comparison of mechanical pretreatment methods for the enhancement of anaerobic digestion of pulp and paper waste activated sludge Water Environ. Res., 84 (2012), pp. 497-505, 10.2175/106143012X13347678384602

Everglades foundation, 2016 Everglades Foundation George Barley Water Prize http://www.barleyprize.com/ (2016)

Farooq et al., 2003 R. Farooq, F.K. Lin, S.F. Shaukat, J.J. Huang Sonochemical degradation of organophosphorus pesticide in dilute aqueous solutions J. Environ. Sci., 15 (2003), pp. 710-714

Filippeli, 2002 G. Filippeli The global phosphorus cycle Rev. Mineral. Geochem, 48 (2002), pp. 391-426, $10.2138 / \mathrm{rmg} .2002 .48 .10$

Ged and Boyer, 2013 E.C. Ged, T.H. Boyer Molecular weight distribution of phosphorus fraction of aquatic dissolved organic matter Chemosphere, 91 (2013), pp. 921-927, 10.1016/i.chemosphere.2013.01.113

Gerstle and Albrinck, 1982 R.W. Gerstle, D.N. Albrinck Atmospheric emissions of metals from sewage sludge incineration J. Air Pollut. Control Assoc., 32 (1982), pp. 1119-1123, 10.1080/00022470.1982.10465519

Gong et al., 2015 C. Gong, J. Jiang, D. Li Ultrasound coupled with Fenton oxidation pre-treatment of sludge to release organic carbon, nitrogen and phosphorus Sci. Total Environ., 532 (2015), pp. 495-500, 10.1016/i.scitotenv.2015.05.131

Gu et al., 2011 A.Z. Gu, L. Liu, J.B. Neethling, H.D. Stensel, S. Murthy Treatability and fate of various phosphorus fractions in different wastewater treatment processes Water Sci. Technol., 63 (2011), pp. 804-810, 10.2166/wst.2011.312

Haug et al., 1978 R.T. Haug, D.C. Stuckey, J.M. Gossett, P.L. Mccarty Effect of thermal pretreatment on digestibility and dewaterability of organic sludges J. Water Pollut. Control Fed., 50 (1978), pp. 73-85, 10.2307/25039508

Henze et al., 2008 M. Henze, M.C.M. van Loosdrecht, G.A. Ekama, D. Brdjanovic Biological Wastewater Treatment IWA Publishing, London, UK (2008)

Huchzermeier and Tao, 2012 M.P. Huchzermeier, W. Tao Overcoming challenges to struvite recovery from anaerobically digested dairy manure Water Environ. Res., 84 (2012), pp. 34-41, $10.2175 / 106143011 \times 13183708018887$

Jarvie et al., 2006 H.P. Jarvie, C. Neal, P.J.A. Withers Sewage-effluent phosphorus: a greater risk to river eutrophication than agricultural phosphorus? Sci. Total Environ., 360 (2006), pp. 246-253, 10.1016/j.scitotenv.2005.08.038

Jin et al., 2009 Y. Jin, Z. Hu, Z. Wen Enhancing anaerobic digestibility and phosphorus recovery of dairy manure through microwave-based thermochemical pretreatment Water Res., 43 (2009), pp. 3493-3502, 10.1016/j.watres.2009.05.017

Kampas et al., 2007 P. Kampas, S.A. Parsons, P. Pearce, S. Ledoux, P. Vale, J. Churchley, E. Cartmell Mechanical sludge disintegration for the production of carbon source for biological nutrient removal Water Res., 41 (2007), pp. 1734-1742, 10.1016/j.watres.2006.12.044 
Karl and Björkman, 2001 D.M. Karl, K.M. Björkman Phosphorus cycle in seawater: dissolved and particulate pool inventories and selected phosphorus fluxes Methods Microbiol., 30 (2001), pp. 239-270, 10.1016/S0580-9517(01)30048-X

Kenge et al., 2009 A. Kenge, P.H. Liao, K.V. Lo Solubilization of municipal anaerobic sludge using microwave-enhanced advanced oxidation process J. Environ. Sci. Health A Tox. Hazard. Subst. Environ. Eng., 44 (2009), pp. 502-506, 10.1080/10934520902719944

Khanal et al., 2007 S.K. Khanal, D. Grewell, S. Sung, J. (Hans) van Leeuwen Ultrasound applications in wastewater sludge pretreatment: a review Crit. Rev. Environ. Sci. Technol., 37 (2007), pp. 277$313, \underline{10.1080 / 10643380600860249}$

Kim et al., 2003 J. Kim, C. Park, T. Kim, M. Lee, S. Kim, S. Eung-wook Kim, J. Lee Effects of various pretreatments for enhanced anaerobic digestion with waste activated sludge J. Biosci. Bioeng., 95 (2003), pp. 271-275, 10.1016/S1389-1723(03)80028-2

Kroiss et al., 2011 H. Kroiss, H. Rechberger, L. Egle Phosphorus in water quality and waste management Integrated Waste Management - Volume II (2011), pp. 181-214, 10.5772/18482

Kuroda et al., 2002 A. Kuroda, N. Takiguchi, T. Gotanda, K. Nomura, J. Kato, T. Ikeda, H. Ohtake A simple method to release polyphosphate from activated sludge for phosphorus reuse and recycling Biotechnol. Bioeng., 78 (2002), pp. 333-338, 10.1002/bit.10205

Le Corre et al., 2009 K.S. Le Corre, E. Valsami-Jones, P. Hobbs, S.A. Parsons Phosphorus recovery from wastewater by struvite crystallization: a review Crit. Rev. Environ. Sci. Technol., 39 (2009), pp. 433-477, 10.1080/10643380701640573

Lean, 1973 D.R.S. Lean Movements of phosphorus between its biologically important forms in Lake water J. Fish. Res. Board Can., 30 (1973), pp. 1525-1536, 10.1139/f73-242

Lemming et al., 2017 C. Lemming, S. Bruun, L.S. Jensen, J. Magid Plant availability of phosphorus from dewatered sewage sludge, untreated incineration ashes, and other products recovered from a wastewater treatment system J. Plant Nutr. Soil Sci., 180 (2017), pp. 779-787, 10.1002/ipln.201700206

Levin and Shapiro, 1965 G.V. Levin, J. Shapiro Metabolic uptake of phosphorus by wastewater organisms Water Pollut. Control Fed., 37 (1965), pp. 800-821, 10.2307/25035307

Li and Brett, 2015 B. Li, M.T. Brett The relationship between operational and bioavailable phosphorus fractions in effluents from advanced nutrient removal systems Int. J. Environ. Sci. Technol., 12 (2015), pp. 3317-3328, 10.1007/s13762-015-0760-y

Liao et al., 2005a P. Liao, W. Wong, K. Lo Release of phosphorus from sewage sludge using microwave technology J. Environ. Eng. Sci., 4 (2005), pp. 77-81, 10.1139/S04-056

Liao et al., 2005b P. Liao, W. Wong, K. Lo Advanced oxidation process using hydrogen peroxide/microwave system for solubilization of phosphate J. Environ. Sci. Health A, 40 (2005), pp. 1753-1761, 10.1081/ESE-200068038

Lim and Wang, 2013 J.W. Lim, J.Y. Wang Enhanced hydrolysis and methane yield by applying microaeration pretreatment to the anaerobic co-digestion of brown water and food waste Waste Manag., 33 (2013), pp. 813-819, 10.1016/j.wasman.2012.11.013

Liu et al., 2008 Y. Liu, G. Villalba, R.U. Ayres, H. Schroder Global phosphorus flows and environmental impacts from a consumption perspective J. Ind. Ecol., 12 (2008), pp. 229-247, 10.1111/j.1530$\underline{9290.2008 .00025 . x}$ 
Macintosh et al., 2018 K. Macintosh, B.K. Mayer, R. McDowell, S. Powers, L.A. Baker, T. Boyer, B.E.

Rittmann Managing diffuse phosphorus at the source versus at the sink Environ. Sci. Technol.

(2018) (In Review)

Marin et al., 2010 J. Marin, K.J. Kennedy, C. Eskicioglu Effect of microwave irradiation on anaerobic degradability of model kitchen waste Waste Manag., 30 (2010), pp. 1772-1779, 10.1016/j.wasman.2010.01.033

Marti et al., 2008 N. Marti, A. Bouzas, A. Seco, J. Ferrer Struvite precipitation assessment in anaerobic digestion processes Chem. Eng. J., 141 (2008), pp. 67-74, 10.1016/j.cej.2007.10.023

Mavinic and Koch, 2003 D.S. Mavinic, F.A. Koch Release of phosphorus from biological nutrient removal sludges: a study of sludge pretreatment methods to optimize phosphorus release for subsequent recovery purposes J. Environ. Eng. Sci., 2 (2003), pp. 369-381, 10.1139/s03-044

Mayer et al., 2013 B.K. Mayer, D. Gerrity, B.E. Rittmann, D. Reisinger, S. Brandt-Williams Innovative strategies to achieve low total phosphorus concentrations in high water flows Crit. Rev. Environ. Sci. Technol., 43 (2013), pp. 409-441, 10.1080/10643389.2011.604262

Mayer et al., 2016 B.K. Mayer, L.A. Baker, T.H. Boyer, P. Drechsel, M. Gifford, M.A. Hanjra, P. Parameswaran, J. Stoltzfus, P. Westerhoff, B.E. Rittmann Total value of phosphorus recovery Environ. Sci. Technol., 50 (2016), pp. 6606-6620, 10.1021/acs.est.6b01239

McKelvie, 2005 I.D. McKelvie Separation, preconcentration and speciation of organic phosphorus in environmental samples Benjamin L. Turner, Emmanuel Frossard, D.S. Baldwin (Eds.), Organic Phosphorus in the Environment, CABI Publishing, Cambridge, MA (2005), pp. 1-20, $10.1079 / 9780851998220.0000$

Mehta et al., 2015 C.M. Mehta, W.O. Khunjar, V. Nguyen, S. Tait, D.J. Batstone Technologies to recover nutrients from waste streams: a critical review Crit. Rev. Environ. Sci. Technol., 45 (2015), pp. 385-427, 10.1080/10643389.2013.866621

Melamane et al., 2007 X. Melamane, R. Tandlich, J. Burgess Anaerobic digestion of fungally pre-treated wine distillery wastewater Afr. J. Biotechnol., 6 (2007), pp. 1990-1993

Meyer and Bester, $2004 \mathrm{~J}$. Meyer, K. Bester Organophosphate flame retardants and plasticisers in wastewater treatment plants J. Environ. Monit., 6 (2004), p. 599, 10.1039/b403206c

Miller et al., 1969 D. Miller, G. Kroll, U. Strauss Degradation of polyphosphates in solution:IV catalytic effect of divalent metal ions on trimetaphosphate formation J. Am. Chem. Soc., 91 (1969), pp. 9882-9884, 10.1021/ja01052a076

Min et al., 2007 S. Min, G.A. Evrendilek, H.Q. Zhang Pulsed electric fields: processing system, microbial and enzyme inhibition, and shelf life extension of foods IEEE Trans. Plasma Sci., 35 (2007), pp. 59-73, 10.1109/TPS.2006.889290

Monbet et al., 2009 P. Monbet, I.D. McKelvie, P.J. Worsfold Dissolved organic phosphorus speciation in the waters of the Tamar estuary (SW England) Geochim. Cosmochim. Acta, 73 (2009), pp. 10271038, 10.1016/i.gca.2008.11.024

Morse et al., 1998 G.K. Morse, S.W. Brett, J.A. Guy, J.N. Lester Review: phosphorus removal and recovery technologies Sci. Total Environ., 212 (1998), pp. 69-81, 10.1016/S0048-9697(97)00332$\underline{x}$

Mottet et al., 2009 A. Mottet, J.P. Steyer, S. Déléris, F. Vedrenne, J. Chauzy, H. Carrère Kinetics of thermophilic batch anaerobic digestion of thermal hydrolysed waste activated sludge Biochem. Eng. J., 46 (2009), pp. 169-175, 10.1016/j.bej.2009.05.003 
Mshandete et al., 2005 A. Mshandete, L. Björnsson, A.K. Kivaisi, S.T. Rubindamayugi, B. Mattiasson Enhancement of anaerobic batch digestion of sisal pulp waste by mesophilic aerobic pretreatment Water Res., 39 (2005), pp. 1569-1575, 10.1016/i.watres.2004.11.037

Müller, 2000 J.A. Müller Pretreatment processes for the recycling and reuse of sewage sludge Water Sci. Technol., 42 (2000), pp. 167-174

Murphy, 2007 S. Murphy BASIN: General Information on Phosphorus [WWW Document] URL http://bcn.boulder.co.us/basin/data/NEW/info/TP.html (2007)

Muthangya et al., 2009 M. Muthangya, A.M. Mshandete, A.K. Kivaisi Enhancement of anaerobic digestion of sisal leaf decortication residues by biological pre-treatment ARPN J. Agric. Biol. Sci., 4 (2009), pp. 66-73

Neethling et al., 2010 J.B. Neethling, D. Clark, A. Pramanik, H.D. Stensel, J. Sandino, R. Tsuchihashi WERF Nutrient Challenge investigates limits of nutrient removal technologies Water Sci. Technol., 61 (2010), pp. 945-953, 10.2166/wst.2010.617

Neethling et al., 2013 J.B. Neethling, H.D. Stensel, H. David Nutrient species implications for technology performance and water quality impacts Proc. Water Environ. Fed. (2013), pp. 152-171, $\underline{10.2175 / 193864713813525437}$

Ohlinger et al., 1998 K.N. Ohlinger, T.M. Young, E.D. Schroeder Predicting struvite formation in digestion Water Res., 32 (1998), pp. 3607-3614, 10.1016/S0043-1354(98)00123-7

Parsons, 2004 S. Parsons Advanced Oxidation Processes for Water and Wastewater Treatment IWA Publishing, London, UK (2004)

Peccia and Westerhoff, $2015 \mathrm{~J}$. Peccia, P. Westerhoff We should expect more out of our sewage sludge Environ. Sci. Technol., 49 (2015), pp. 8271-8276, 10.1021/acs.est.5b01931

Piveteau et al., 2017S. Piveteau, S. Picard, P. Dabert, M.L. Daumer Dissolution of particulate phosphorus in pig slurry through biological acidification: a critical step for maximum phosphorus recovery as struvite Water Res., 124 (2017), pp. 693-701, 10.1016/i.watres.2017.08.017

Poyatos et al., 2010 J.M. Poyatos, M.M. Muñio, M.C. Almecija, J.C. Torres, E. Hontoria, F. Osorio Advanced oxidation processes for wastewater treatment: state of the art Water Air Soil Pollut., 205 (2010), pp. 187-204, 10.1007/s11270-009-0065-1

Qin et al., 2015 C. Qin, H. Liu, L. Liu, S. Smith, D.L. Sedlak, A.Z. Gu Bioavailability and characterization of dissolved organic nitrogen and dissolved organic phosphorus in wastewater effluents Sci. Total Environ., 511 (2015), pp. 47-53, 10.1016/j.scitotenv.2014.11.005

Qureshi et al., 2006 A. Qureshi, K.V. Lo, D.S. Mavinic, P.H. Liao, F. Koch, H. Kelly Dairy manure treatment, digestion and nutrient recovery as a phosphate fertilizer J. Environ. Sci. Health $B, 41$ (2006), pp. 1221-1235, 10.1080/03601230600857098

Reynolds and Davies, 2001 C.S. Reynolds, P.S. DaviesSources and bioavailability of phosphorus fractions in freshwaters: a British perspective Biol. Rev. Camb. Philos. Soc., 76 (2001), pp. 27-64, 10.1111/j.1469-185X.2000.tb00058.x

Riau et al., 2012 V. Riau, M.A. De la Rubia, M. Pérez Assessment of solid retention time of a temperature phased anaerobic digestion system on performance and final sludge characteristics J. Chem. Technol. Biotechnol., 87 (2012), pp. 1074-1082, 10.1002/jctb.3709

Rittmann et al., 2008 B.E. Rittmann, H.S. Lee, H. Zhang, J. Alder, J.E. Banaszak, R. Lopez Full-scale application of focused-pulsed pre-treatment for improving biosolids digestion and conversion to methane Water Sci. Technol., 58 (2008), pp. 1895-1901, 10.2166/wst.2008.547 
Rittmann et al., 2011 B.E. Rittmann, B. Mayer, P. Westerhoff, M. Edwards Capturing the lost phosphorus Chemosphere, 84 (2011), pp. 846-853, 10.1016/j.chemosphere.2011.02.001

Salerno et al., 2009 M.B. Salerno, H.-S. Lee, P. Parameswaran, B.E. Rittmann Using a pulsed electric field as a pretreatment for improved biosolids digestion and methanogenesis Water Environ. Res., 81 (2009), pp. 831-839, 10.2175/106143009X407366

Sañudo-Wilhelmy, 2006 S.A. Sañudo-Wilhelmy A phosphate alternative Nature, 439 (2006), pp. 25-26, $10.1038 / 439025 a$

Schröder et al., 2010 J.J. Schröder, D. Cordell, A.L. Smit, A. Rosemarin Sustainable use of phosphorus Rep. 357, Plant Res. Int. Part Waganigen UR 140 (2010)

Seviour et al., 2003 .J. Seviour, T. Mino, M. Onuki The microbiology of biological phosphorus removal in activated sludge systems FEMS Microbiol. Rev., 27 (2003), pp. 99-127, 10.1016/S01686445(03)00021-4

Singh and Agrawal, 2008 R.P. Singh, M. Agrawal Potential benefits and risks of land application of sewage sludge Waste Manag., 28 (2008), pp. 347-358, 10.1016/j.wasman.2006.12.010

Singh and Walker, 2006 B.K. Singh, A. Walker Microbial degradation of organophosphorus compounds FEMS Microbiol. Rev. (2006), 10.1111/j.1574-6976.2006.00018.x

Stark et al., 2006 K. Stark, E. Plaza, B. Hultman Phosphorus release from ash, dried sludge and sludge residue from supercritical water oxidation by acid or base Chemosphere, 62 (2006), pp. 827832, 10.1016/i.chemosphere.2005.04.069

Stephens et al., 2004 H.M. Stephens, J.B. Neethling, M. Benisch, A.Z. Gu, H.D. Stensel Comprehensive analysis of full-scale enhanced biological phosphorus removal facilities Proc. Water Environ. Fed., 2004 (2004), pp. 89-107, 10.2175/193864704784136685

Strauss and Day, 1967 U.P. Strauss, J.W. Day Degradation of polyphosphates in solution. II. Hydrolysis of sodium hexaphosphate J. Polym. Sci., Part C: Polym. Symp., 16 (1967), pp. 2161-2169, 10.1002/polc. 5070160430

Strauss and Krol, 1967 U.P. Strauss, G.J. Krol Degradation of polyphosphates in solution. III. Hydrolysis of linear long-chain sodium polyphosphate J. Polym. Sci., Part C: Polym. Symp., 16 (1967), pp. 2171-2179, 10.1002/polc.5070160431

Strauss and Treitler, 1956 U.P. Strauss, T.L. Treitler Degradation of polyphosphates in solution. I. Kinetics and mechanism of the hydrolysis at branching points in polyphosphate chains J. Am. Chem. Soc., 78 (1956), pp. 3553-3557, 10.1021/ja01596a001

Sung and Santha, 2001 S. Sung, H. Santha Performance of temperature-phased anaerobic digestion (TPAD) system treating dairy cattle wastes Tamkang J. Sci. Eng., 4 (2001), pp. 301-310, 10.1016/S0043-1354(02)00498-0

Tanaka and Kamiyama, $2002 \mathrm{~S}$. Tanaka, K. Kamiyama Thermochemical pretreatment in the anaerobic digestion of waste activated sludge Water Sci. Technol. (2002), pp. 173-179, 10.1016/S02731223(97)00169-8

Theriot and Grunden, 2011 C.M. Theriot, A.M. Grunden Hydrolysis of organophosphorus compounds by microbial enzymes Appl. Microbiol. Biotechnol. (2011), 10.1007/s00253-010-2807-9

Thilo and Wieker, $1961 \mathrm{E}$. Thilo, W. Wieker Study of degradation of polyphosphates in aqueous solution J. Polym. Sci., 53 (1961), pp. 55-59, 10.1002/pol.12005315808

Tiehm et al., $2001 \mathrm{~A}$. Tiehm, K. Nickel, M. Zellhorn, U. Neis Ultrasonic waste activated sludge disintegration for improving anaerobic stabilization Water Res., 35 (2001), pp. 2003-2009 
Toreci et al., 2009 I. Toreci, K.J. Kennedy, R.L. Droste Evaluation of continuous mesophilic anaerobic sludge digestion after high temperature microwave pretreatment Water Res., 43 (2009), pp. 1273-1284, 10.1016/i.watres.2008.12.022

Trebše and Arčon, 2003 P. Trebše, I. Arčon Degradation of organophosphorus compounds by X-ray irradiation Radiat. Phys. Chem., 67 (2003), pp. 527-530, 10.1016/S0969-806X(03)00099-9

Trebše and Franko, 2002 P. Trebše, M. Franko Laser-induced degradation of organophosphorus compounds Int. J. Photoenergy, 4 (2002), pp. 41-44, 10.1155/S1110662X02000077

USEPA, 1986 USEPA Quality Criteria for Water United States Environ. Prot. Agency, Off. Water Regul. Stand. 395 (1986) (doi:440/5-86-001)

USEPA, 1994 USEPA Land Application of Sewage Sludge United States Environ. Prot. Agency, Off. Enforc. Compliance Assur (1994) (doi:EPA/831-B-93-002b)

USEPA, 1995 USEPA Technical Guidance Manual for Developing Total Maximum Daily Loads United States Environ. Prot. Agency, Off. Water 254 (1995) (doi:EPA 823-B-95-007)

USEPA, 1998 USEPA National Strategy for the Development of Regional Nutrient Criteria United States Environ. Prot. Agency, Off. Water 53 (1998) (doi:822-R-98-002)

USEPA, 2007 USEPA Advanced Wastewater Treatment to Achieve Low Concentration of Phosphorus United States Environ. Prot. Agency, Off. Water Watersheds Reg. 73 (2007) (doi:EPA 910-R-07002)

USEPA, 2010 USEPA Nutrient Control Design Manual United States Environ. Prot. Agency, Off. Res. Dev. Natl. Risk Manag. Res. Lab. 369 (2010) (doi:EPA/600/R-10/100)

Uysal et al., 2010 A. Uysal, Y.D. Yilmazel, G.N. Demirer The determination of fertilizer quality of the formed struvite from effluent of a sewage sludge anaerobic digester J. Hazard. Mater., 181 (2010), pp. 248-254, 10.1016/i.jhazmat.2010.05.004

Van Loosdrecht et al., 1997 M.C.M. Van Loosdrecht, C.M. Hooijmans, D. Brdjanovic, J.J. Heijnen Biological phosphate removal processes Appl. Microbiol. Biotechnol., 48 (1997), pp. 289-296, $10.1007 / \mathrm{s} 002530051052$

Venkatesan et al., 2018 A.K. Venkatesan, W. Gan, H. Ashani, P. Herckes, P. Westerhoff Size exclusion chromatography with online ICP-MS enables molecular weight fractionation of dissolved phosphorus species in water samples Water Res., 133 (2018), pp. 264-271, 10.1016/j.watres.2018.01.048

Wang and $\mathrm{Xu}, 2012 \mathrm{~J}$ J.L. Wang, L.J. Xu Advanced oxidation processes for wastewater treatment: formation of hydroxyl radical and application Crit. Rev. Environ. Sci. Technol., 42 (2012), pp. $251-325,10.1080 / 10643389.2010 .507698$

Wang and Zhao, $2009 \mathrm{X}$. Wang, Y. Zhao A bench scale study of fermentative hydrogen and methane production from food waste in integrated two-stage process Int. J. Hydrog. Energy (2009), 10.1016/i.ijhydene.2008.09.100

Wang et al., 2005 J. Wang, J.G. Burken, X. (Jackie) Zhang, R. Surampalli Engineered struvite precipitation: impacts of component-ion molar ratios and pH J. Environ. Eng., 131 (2005), pp. 1433-1440, 10.1061/(ASCE)0733-9372(2005)131:10(1433)

Wang et al., 2010 X. Wang, Z. Qiu, S. Lu, W. Ying Characteristics of organic, nitrogen and phosphorus species released from ultrasonic treatment of waste activated sludge J. Hazard. Mater., 176 (2010), pp. 35-40, 10.1016/i.jhazmat.2009.10.115

Werther and Ogada, $1999 \mathrm{~J}$. Werther, T. Ogada Sewage sludge combustion Prog. Energy Combust. Sci., 25 (1999), pp. 55-116, 10.1016/S0360-1285(98)00020-3 
White et al., 2004 J.R. White, K. Ramesh Reddy, M.Z. Moustafa Influence of hydrologic regime and vegetation on phosphorus retention in Everglades stormwater treatment area wetlands Hydrol. Process., 18 (2004), pp. 343-355, 10.1002/hyp.1379

Wong et al., 2006 W. Wong, W. Chan, P. Liao, K. Lo, D. Mavinic Exploring the role of hydrogen peroxide in the microwave advanced oxidation process: Solubilization of ammonia and phosphates $\mathrm{J}$. Environ. Eng. Sci., 5 (2006), pp. 459-465, 10.1139/S06-020

Worsfold et al., 2016 P. Worsfold, I. Mckelvie, P. Monbet Determination of phosphorus in natural waters: a historical review Anal. Chim. Acta, 918 (2016), pp. 8-20, 10.1016/j.aca.2016.02.047

Yang et al., 2017 Y. Yang, X. Shi, W. Ballent, B.K. Mayer Biological phosphorus recovery: review of current progress and future needs Water Environ. Res., 89 (2017), pp. 2122-2135, $10.2175 / 106143017 X 15054988926424$

Yin et al., 2007 G. Yin, P. Huang Liao, K. Victor Lo, K.L.O. Victor An ozone/hydrogen peroxide/microwave- enhanced advanced oxidation process for sewage sludge treatment $\mathrm{J}$. Environ. Sci. Health A, 42 (2007), pp. 1093-4529, 10.1080/10934520701418706

Yin et al., 2008 G.Q. Yin, P.H. Liao, K.V. Lo Microwave enhanced advanced oxidation process for sewage sludge treatment: the effects of ozone addition J. Environ. Eng. Sci., 7 (2008), pp. 115-122, 10.1139/S07-042

Yoshimura et al., 2007 T. Yoshimura, J. Nishioka, H. Saito, S. Takeda, A. Tsuda, M.L. Wells Distributions of particulate and dissolved organic and inorganic phosphorus in North Pacific surface waters Mar. Chem., 103 (2007), pp. 112-121, 10.1016/i.marchem.2006.06.011

Yu, $2002 \mathrm{~J} .-\mathrm{J}$. Yu Removal of organophosphate pesticides from wastewater by supercritical carbon dioxide extraction Water Res., 36 (2002), pp. 1095-1101, 10.1016/S0043-1354(01)00293-7

Yuan et al., 2012 Z. Yuan, S. Pratt, D.J. Batstone Phosphorus recovery from wastewater through microbial processes Curr. Opin. Biotechnol., 23 (2012), pp. 878-883, 10.1016/j.copbio.2012.08.001

Zeng and Li, $2006 \mathrm{~L}$. Zeng, X. Li Nutrient removal from anaerobically digested cattle manure by struvite precipitation J. Environ. Eng. Sci., 5 (2006), pp. 285-294, 10.1139/s05-027 